\title{
Effect of Product-harm Crisis on Customer's Based Brand Equity: The Moderating Role of Attitude towards Brand
}

\author{
Muhamamad Bilal, ${ }^{1, *}$, Muhammad Idrees ${ }^{2}$ \\ ${ }^{1}$ Institute of Management Studies, University of Peshawar, Peshawar, 25000, Khyber Pakhtunkhwa, Pakistan \\ ${ }^{2}$ Institute of Management Sciences, Peshawar, Peshawar, 25000, Khyber Pakhtunkhwa, Pakistan
}

Copyright $\bigcirc 2017$ by authors, all rights reserved. Authors agree that this article remains permanently open access under the terms of the Creative Commons Attribution License 4.0 International License

\begin{abstract}
A company importance can be changed by product-harm crisis (PHC). There are so many cases of PHC where weak response of the company's has resulted in negative effect on brand equity. Still less research studies were conducted on the effect of product-harm crises. The objective of this research is to investigate (a) the effect of PHC on customer's based brand equity (BE) (b) the moderating role of attitude towards brand (ATB) between $\mathrm{PHC}$ and $\mathrm{BE}$. The population of this study consists of nine universities of Peshawar district offering business programs. Two universities were purposively selected. A sample of 200 undergraduate business students has been selected. After reading self-designed newspaper article by sampled undergraduate business students, questionnaires were filled on five and seven points' likert-scales. To investigate the effect of $\mathrm{PHC}$ on $\mathrm{BE}$, simple linear regression was used. In order to measure the before and after effect of stone-walling response of a company on the relationship between $\mathrm{PHC}$ and $\mathrm{BE}$, Wilcoxon signed-rank test was used. Also moderating effect of ATB was measured through SPSS. The overall results demonstrated that relationship between $\mathrm{PHC}$ and BE is statistically significant and negative. Additionally, the inclusion of ATB as a moderator has lessened the negative effects of $\mathrm{PHC}$ on BE. The effect of PHC on BE before stonewalling response was less negative as compared to after.
\end{abstract}

Keywords Product-harm Crisis, Customer's Based Brand Equity, Attitude towards Brand

\section{Introduction}

\subsection{Background Information}

It is the most difficult task of marketing to meet social and human needs profitably (Kotler and Keller, [1]). In this modern era, customer's satisfaction is much difficult task. It is mostly asked question by many companies that what consumers want and how they think (Wood, [2]). Marketing plays vital role in getting loyal customer base as well as developing a strong brand. CEOs identified this contributory role of marketing in the value of firm (Kotler and Keller, [1]). Kotler and Keller [1], in their researches stated that established brands are the key assets to a business as those brands are the source of revenue for companies and customers are willing even to pay extra sum of money in order to get their desired brands and thus showing no hesitation while making purchase decisions, which help in the reduction of marketing costs of a company as well. For many centuries, these mysteries soul have been investigated in the compass of consumer behavior and marketing; nevertheless, it looks orderly and wholesome ending is not yet gained.

Consumer mind frames are getting complex which make profitability unstable. In order to handle such situation, companies call for precise and flexible management, thus pay extra attention and money to get the desired outcomes (Dawar and Pillutla [3]). For many years companies realize those customers profitable which shows repeat purchase behaviors. And also those loyal customers will assist in extending market shares of the company, increase base line, and sustain company's growth. Although customer's loyalty is like precious stone, in order to keep those key customers, brand management is one of the best choices. Brand is a totality of overall attributes that helps in making the product unique (Wood, [2]). A product might be copied, but can't be imitating (Dawar and Lei, [4]). Brand plays the role of personality of the product which states that what the goods and services reveal to the customer and how the customer's emotional feelings when they encounter or use that brand (Wood, [2]). Brand is a source of reputation for a company. Brand is that mark which imprints on the minds of customers. Aaker [5] stated that successful brand can 
retain and attract customers which serve a source of wealth creation for any company.

By 2002 in the USA, there are several cell phones recalled by Consumer Product and Safety Commission because of many cases of explosions and fire accidents, like the Kyocera Smartphone, Kyocera Slider, K400, and 3200 Series, and Verizon Wireless LG-brand (Matos and Rossi, [6]).

Maher [7] in a newspaper article described a situation of a university student who claim bacteria-contaminated taco gave him food poisoning as that taco was purchased from Chipotle restaurant. The restaurant spokesperson justified his company by stating that there company takes all measures to keep the products hygiene and the student that suffered from food poisoning is not because of their food quality but due to some other factors. Thus product harm-crises are having very drastic effects, so every company should ready for it all the time and must practice a good response strategy to that crisis (Davies and Walters, [8]).

Product-harm crises are serious scenario where either product is found to be unsafe, out of order or harmful (Dawar and Pillutla, [3]). Product harm-crisis also states "sudden abruption in the life cycle of product" (Siomkos and Kurzbard, [9]). Product harm-crises should not be underestimated by companies, as they have been finding responsible for having negative effect on sales of recalled products, market share and purchase intentions (Siomkos and Kurzbard, [9]; Pruitt and Peterson, [10]). Product-harm crises make it difficult for the companies to survive.

Marketers have a long history of identifying, considering and targeting the right segment of the market by offering right products. But there are several companies which are continuous engaged in advertising such product or services which are causing economic, physical, or psychological harm (McDaniel et al., [11]; Hill, [12]; Wallendorf, [13]; Nwachukwu et al., [14]).

Product harm-crisis is facing a great challenge in the media world. According to one of the government website, there were several products recalled in 2005, which consists of consumer foods products, medicines, motor tires, and car accessories. Berman's [15] claim that it is the requirement of the situation to recall some of your company's products. If proper actions are taken, it will lead to affect the customers' brand attitude. As attitude is the customers' feeling towards a product that either he/she might favor the product or disfavor.

Fishbein and Ajzen [16], in agreement with Kanouse and Reid [17], stated that attitude is beliefs that a person may have which could either be in favor or oppose of some object. Behavioral intentions are defined as those intentions that a consumer may held to perform certain behaviors.

Shimp and Terence [18] argued that when involvement category is low, attitudes can be shifted from advertisement to brand. If customers are expose to brand advertisements, this helps in formation of brand attitudes as an outcome of brand belief (Lutz and Richard, [19]; Olson and Mitchell, [20]). Attitude is an important research topic in both advertisement and marketing as it is helpful in identifying consumer behavior in terms of brand as well as several studies were conducted in the field of social psychology (Mitchell and Olson, [20]; Eagly and Chaiken, [21]). Two dimensions of attitudes are popular: personal action tendencies relating to the brand and attitude toward the brand (Bagozzi and Richard, [22]; Ostrom and Thomas, [23]).

Mitchell and Olson [24] defined attitude toward the brand as "how an individual evaluation brand internally". According to Giner- Sorolla and Roger [25]), attitude is directional in terms of brand and attitude tells us about the degree of goodness and badness that a individual have towards a brand (Eagly and Chaiken, [21]). Attitude is a internal state however Eagly and Chaiken [21], in their research studies stated that an attitude is an enduring state which energizes behaviors and give it a direction.

Brand equity is defined by many scholars in their studies, as addition of value that a brand gives to its company's product (Aaker, [5]). Brand equity plays important role in the increase of value and utility of the company's products due to its brand name and thus helps in the achievement of long term profits (Ching-Fu Chen and Yu-Ying Chang, [26]). Brand equity is considered as a primary capital of many companies (Ching-Fu et al, [26]).

Cobb-Walgren, Ruble and Donthu [27] designed a brand equity framework from customers' point of view which suggests that consumer's perception of brand helps in the increase of value of a brand.

According to Aaker [5] brand equity as all those attributes which are linked to the brand that either enhance or reduce the value of the product when it is offered to the customers by the company. Aaker [5] also gave five dimensions for the measurement of brand equity: (1) brand awareness, (2) brand loyalty, (3) brand image (brand associations), (4) perceived quality and (5) other proprietary assets.

Based on Aaker's work, Keller [28] defined brand equity in term these above stated dimensions. Keller [29] in his studies defined brand awareness as identifying brand attributes under different scenarios. One the component of brand awareness is brand recognition and other one is brand recall ability. Brand recognition is defined as ability of a consumer to recognize the brand when he or she is exposed to it. Consumer recalls few of the brands although he/she come across several products brand (Keller, [29]).

Brand recognition is about awareness of brand upon the aided recall (Holden, [30]; Laurent et al., [31]; Mariotti, [32]). Brand awareness can be developed and improved by continuous exposure of brand (Keller, [29]). The brand will take root in the minds of customers as the exposure is repeated. Brand awareness shows how strong brand is imprinted on the mind of the customer and easily a he or 
she can recall a brand when cue is given (Ellio, Harris and Baron, [33]).

In order to gain and maintain new numbers of customers, company needs to distinguish there product from others by giving a strong and unique brand identity to their products. An awareness session is also been done so that a customer may recognize and recall their brands and thus will help in accessing customer's minds (Keller, [29]).

In order to make the buyers ready to purchase your products, they need to be made aware of the brand first (Rossiter and Percy, [34]). Brand awareness is the first and difficult stage that makes customer's ready for purchase and gave them the sense of loyalty towards the brand (Ross and Harradine, [35]). Loyal customers give more profits and thus easy to serve as compared to disloyal customers (Rossiter and Percy, [34]).

Brand loyalty is performing both the functions of attitudes as well as behavior (Jacoby and Kyner, [36]). Making purchase again and again doesn't show brand loyalty but purchase with intentions explains loyalty. Brand loyalty shows commitment of positive attitudes and repeat purchases.

There are number of same products offered by many companies at the same time with different brand names. This shows that branding is having greater effectiveness as it helps in repeat purchases as well as brand loyalty (Reichheld, [37]).

Mustafa [38] stated in his research studies that positive brand image helps in maintaining brand loyalty. Stronger the brand image of the company, better will the company position to be distinguish from its competitors. Brand image doesn't include only colors and symbols but it consists of words, and slogans that convey a clear and concise message not only the name (Berry et al., [39]). Self-image of the customers can be achieved by purchasing such products about which customer is having a strong and positive brand image and thus brand image plays contributes in reinforcing their self-image. Park et al., [40] say that brand image is the "understanding consumers drive from the total set of brand-related activities engaged by the firm"

Due to difference in the image of the brands, consumer considers one brand as more superior than other competing brands (Schiffman and Kanuk, [41]). Brands may serve as surety of quality (Aaker, [5]). Consumers once convinced about the quality of the product, they show their loyalty to the brand. Brand names also assist in the recognition of the brand as well as help in making decisions about the purchase of it. Consumer wishes to purchase those brands which have familiar meaning to them as they associates brand image to product quality (Berry et al., [39]). Brand delivers the meaning of quality. Customers feel ease with known brand as compared to unknown brands. That's the reason companies charge even extra price for their products and customers show their willingness to purchase it at higher rates (Elliott, [42]).

\subsection{Problem Statement}

Product-harm crises literature has examined impact of product-harm crises on brand equity and the moderating role of consumer expectations (Dawar et al., [3]). Most research regarding product-harm crises has been conducted in the Western countries (Aikaterini et al., [43]). Because of severe consequences of product harm-crisis, government is getting stricter in their rules and regulations against PHC in order to overcome the occurrences. Many researches in the area of finance and economics showed that those companies which are facing product recalls due to product harm-crises may suffer from large drops in their market share as well as stock prices. Thus these drops in stock prices may rarely be responsible for by the cost of product recall itself (Pruitt and Peterson [10]). Product harm-crisis results in the reduction of brand equity as well as willingness to purchase the product in the future (Shrivastava and Siomkos, [44]). Near to negligence amount of research has explored this concept in the Asian geographies especially in Pakistan. Thus, this concept needs to be investigated in the Asian societies like Pakistan. Previous studies done in Western countries have linked product-harm crises and brand equity. However this association remains undiscovered in Asian societies like Pakistan. A product-harm crisis is the comparatively new and pivotal topic in this marketing arena.

\subsection{Objectives of the Study}

This study is aim at investigating the string between product-harm crisis and customer's brand equity and also the moderating effect of attitude towards brand. Following are the specific objectives of this study.

1. To examine the effect of product-harm crisis on customer's brand equity.

2. To investigate the moderating effect of attitude towards brand on the relationship between product-harm crisis and customer's brand equity.

3. To investigate the average perception of customers regarding product harm-crises before and after stone-walling response by company.

\subsection{Hypothesis of the Study}

Below are the lists of hypotheses of the study:

\section{Hypothesis 1}

$\mathrm{H}_{0}$ : Product harm-crisis has no significant effect on brand equity

$\mathrm{H}_{1:}$ Product harm-crisis has significant effect on brand equity

\section{Hypothesis 2}


$\mathrm{H}_{0 \text { : }}$ Attitude towards brand insignificantly moderates the effect product harm-crisis on brand equity

$\mathrm{H}_{2}$ : Attitude towards brand significantly moderates the effect product harm-crisis on brand equity

\section{Hypothesis 3}

$\mathrm{H}_{0}$ : There is no significant difference between average perception of customers regarding product harm-crisis before and after stone-walling response.

$\mathrm{H}_{3}$ : There is significant difference between average perception of customers regarding product harm-crisis before and after stone-walling response.

\subsection{Significance of the Study}

There are several studies that investigated the most important factors that effects product-harm crisis, like the intensity and amount of media focus (Weinberger and Romeo, [45]), the several types of media roles during product harm-crises (Jolly and Mowen, [46]; Weinberger, [47]), the amount of causalities (Mowen, [48]; Mowen and Ellis, [49]), Attention paid by regulatory agencies during product harm-crisis (Weinberger, [47]), how a company's reputation play role during product harm-crisis (Siomkos and Shrivastava, [50]), the different types of crises (Coombs, [51]; Mitroff and Pearson, [52]), what type of response messages company disseminates during product harm-crisis (Griffin et al., [53]; Jorgensen, [54],[55]), strategies practice by company during product harm-crisis (Siomkos and Kurzbard, [9]), brand loyalty in crises (Cleeren et al., [56]), the role of CSR in product harm-crisis (Matos and Rossi, [6]; Klein and Dawar, [57]), role of safety on defective products (Griffin et al., [58]), and customer's prior expectations in product harm-crisis (Dawar and Pillutla, [3]), product recall strategies before crises (Matos and Rossi, [6]) and Baolong Ma et al., [59] has examined the effect of product-harm crisis on a brand's performance and market structure.

This study is examining the effect of product-harm crises on attitude towards brand and customer's based brand equity. This study will help all the companies of Pakistan to understand the severity and consequences of product-harm crises and also effects of those actions on customer's based brand equity and attitudes towards brand. This will make the marketing managers of all companies of the world to realize the severity of PHC and also it will help them to take some corrective measures in order to safe guard their companies stake and as well as their customer's brand equity. They can also improve the image of the companies in PHC.

\section{Literature Review}

A product-harm crisis is an increasingly common occurrence. The attention it attracts appears to be the result of a combination of factors - mass media exposure, increased consumer sophistication and the general population having an overall heightened awareness about recalls and consumer safety. These factors contribute to the likelihood of substantial damage to an organization's brand equity in the event of a recall. This chapter presents literature relevant to the central concept of product-harm crisis; the effect of product-harm crisis on the brand attitude as well as on the brand equity.

\subsection{Product Harm Crisis}

According to Elliott et al. [33], a little and weak attention is paid towards the consequences and management of product harm crisis. Also little importance was paid to the effect of organizational responses to the crisis in respect to consumer perceptions. The most important factors effecting product harm-crisis, like the intensity and amount of media focus (Weinberger and Romeo, [45]), the several types of media roles during product harm-crises (Jolly and Mowen, [46]; Weinberger, [47]), the amount of causalities (Mowen, [48]; Mowen and Ellis, [60]), Attention paid by regulatory agencies during product harm-crisis (Weinberger, [47]), how a company's reputation play role during product harm-crisis (Siomkos and Shrivastava, [50]), the different types of crises (Coombs, [51]; Mitroff and Pearson, [52]), what type of response messages company disseminates during product harm-crisis (Griffin et al., [58]; Jorgensen, [54],[55]), strategies practice by company during product harm-crisis (Siomkos and Kurzbard, [9]) , brand loyalty in crises (Cleeren et al., [56]), the role of CSR in product harm-crisis (Matos and Rossi, [6]; Klein and Dawar, [57]), role of safety on defective products (Griffin et al., [58]), and customer's prior expectations in product harm-crisis (Dawar and Pillutla, [3]), product recall strategies before crises (Matos and Rossi, [6]) and Baolong Ma et al., [59] has examined the effect of product-harm crisis on a brand's performance and market structure.

According to Eilert, Kalaignanam, Jayachandran, Swartz \& Tracey ([116]), Company recalled there malfunctioned products in order to minimize harm to target consumers and also loss to the company. Thus Eilert et al., [116] in their study investigate the effects of product recall on the stock market as well as time for recalling the effected product. Also there research investigated the moderating role of brand characteristics on the relationship between the time to recall damage product and its effects on stock market. Automobile industry between 1992 and 2012 was considered for collecting their data sample of 381 recall cases. There resulted revealed that the relationship between time to recall product and problem severity stronger when the brand is diverse and vice versa. Therefore their study suggested that time to recall product under severe problem do effect manager and policy maker decisions. 
According to Hsu \& Lawrence, ([117]), investigate the role of social media in PHC. Their study investigated the relationship between social media and company's shareholder value by considering 185 recall announcements as a sample of their study. Their study suggested that the negative results of e-word-of-mouth (eWOM) on firm value lower for firms having strong brand equity and also product recall having negative abnormal returns for the firms.

Negative information is disseminated among customers during product harm-crisis about product and its company. As a result, the attitudes of the consumers get negatively changed after product harm-crisis (Siomkos and Kurzbard, [9]). Certain prompt actions are necessary for the company in order to bring back the customers towards purchase its products. There are several studies on victim compensation; accepting responsibilities and proactive product recall (Siomkos and Kurzbard, [9]; Siomkos and Malliaris, [61]; Siomkos and Shrivastava, [50]).

Aikaterini et al., [43] in his research examined that if company is socially responsible, then consumers usually forget product harm crisis, especially in the case of voluntary recall strategy. The devastating effect of product harm-crisis not only changes the brand's portfolio but also it changes the consumer's perception towards company brands (Roehm and Tybout, [62]).

Several studies state the effect of PHC on consumer responses. Knowledge about the company's brand as well as goodwill affect the consumer attitude towards brand (Mowen et al., [48]; Siomkos and Kurzbard, [9]; Dean, [63]; Siomkos and Shrivartara, [50]; Dawar and Lei, [4]), the consumer's brand loyalty during PHC (Cleeren et al., [56]), external factors role in product harm-crisis (Siomkos and Kurzbard, [9];Jolly and Mowen, [46]; Siomkos and Malliaris, [61]; Siomkos, [64]), company responses to the incidents (Shrivastava and Siomkos, [44]; Wiener and Mowen, [65]; Siomkos, [64]; Dawar and Pillutla, [3]), role of blame and responsibility (Folkes, [66], [67]; Mowen et al., [60]; Richins, [68]; Laczniak et al., [69]; Griffin et al., [53]; Laufer and Coombs, [70]), disaster of product-harm crisis (Mowen and Ellis, [60]; Mowen, [48]; Kelly and Campbell, [71]; Tedeschi and Nesler, [72]; Laufer et al., [73]), pre-crisis category advertising and usage (Cleeren et al., [56]), the role of CSR (Klein and Dawar, [57]; Matos and Rossi, [6]), safety measures on the defective products (Griffin et al., [58]), before defects, product recall approach (Matos and Rossi, [6]), and customer's prior perceptions (Dawar and Pillutla, [3]).

Most of the research studies related to PHC outcomes have emphasized on consumer responses, including purchase aims of the malfunction products (Klein and Dawar, [57]; Dawar and Pillutla, [3]; Matos and Rossi, [6]), Customer's purchase intentions towards defective products (Matos and Rossi, [6]; Siomkos and Kurzbard, [9]; Griffin et al., [58]), re-purchase aspiration (Folkes and Kotsos, [74]; Folkes, [67], [66]), company's aims to complain
(Klein and Dawar, [57]; Folkes and Kotsos, [74]; Folkes, [67], [66]; Laczniak et al., [69]), company's aims to change the affected brand (Klein and Dawar, [6]; Laczniak et al., [69]; Folkes, [67]), trying new products of the defective company (Mowen and Ellis, [60]; Mowen, [48]), and approving affected product to other - having positive statements about the company and its products (Matos and Rossi, [6]). Cleeren et al. [56] considered the purchase behavior of the consumers towards the inoperative brand.

Slovic [75] considered the consumer's risk factors while getting defective products. The more the harm caused by defective product, greater consumer will perceive danger and as a result consumer will like to go for those products which less their risk factor (Paswan et al., [76]).

Siomkos and Shrivartara [50] got important role in the time of product crisis. The war of the defective products are getting more intense as media allure the attentions of new contestants, namely, interest groups, the channels, civic leaders, governing agents, state and local officials, etc. These external players tactic tends to change. Like, they can join the affected company, giving advantage to opponents by destroying company, or hurt the complete product line. According to Siomkos [64] product-harm crisis may alter due to intrusion of external factors, such as the regulatory and press agencies. Conclusion states that negative information increases the danger level caused by product harm-crisis. During crises, the mass media play important role in the dissemination of information (Tsang, [77]). They provide inappropriate information to lure consumers (Eagle et al., [78]). Media coverage is having negative influence in the era of technology (Frewer and Shepherd, [79]) elevation of risk factors (Kasperson et al., [80]).

Furthermore, Huang [81] examined, four crises response messages in terms of three factors in communicating these messages: consistency, quickness, and prompt response. Compensation strategy is good to overcome the effect of product -harm crisis. The aim of this strategy is to build public relations and to communicate well in the times of crisis. Furthermore, organizational responses affect the PHC. Shrivastava and Siomkos [44] illustrated four basic organizational responses. (a) Denial/Stonewalling: the company denies the responsibility for the harm caused by company product, (b) Involuntary recall: company recall product upon regulatory agencies request, (c) Voluntary recall: without the intervention of government, the company chooses to recall its product and (d) Super effort: the company tries to improve image by compensating the victims and recalls the harmful product immediately.

Relevant literature supported that having good reputation of the company, can protect the devastating effect of product harm-crisis (Jones et al., [82]; Mak, [83]). As Fombrun and VanRiel [84] declare that the damages of the crises may reduce as the company held a positive reputation. Some of the studies divulge that companies in a high injury crisis are less at benefit as compared to low 
injury (Mowen and Ellis, [60]).

Another paper examined how country of origin, affects the severity of product harm-crisis. The results stated that when the country of manufacturing (COM) is not known the severity of product harm-crisis is high in that case but if the COM is known then attribution of blame has lessen affects (Laufer et al., [85]).

Yubo et al., [86] in their research investigated that firm's sales as well as financial values get change as a result of PHC. The research suggested that firms should practice passive response strategy as compared to proactive response strategy in product harm-crises.

Baolong et al., [59] have examined that how brand's performance and market structure is being affected by product harm-crisis. They took data of Nestlé product-harm crisis in China. The results stated that product harm-crisis cause change in market structure and customer behavior. Thus show a negative effect on brand performance of Nestlé.

\subsection{Attitude towards Brand}

There are several studies in the area of different attitude models which made a clear and significant support for the attitude towards advertisement (Nancy and Surendra, [87]; Fishbein et al., [16]). Prior research studies have clearly suggested that the aspect of emotions in advertisement can influence the brand choices (Heath, [88]).

Gardner [89] in his study investigated the consumer attitude towards brand in relation to advertisement. Thus findings of his study show positive effects of advertisement on attitude towards brand (Mitchell and Olson, [24]).

Fishbein's attitude theory clearly defines those feelings of the customers which lead towards the attitude improvement and change. Mitchell and Olson [24] conducted a research in order to check the preposition for consumer's attitude in respect to product traits and brand by considering advertising effects study only. An advertisement was displayed in front of targeted number of respondents and the results of that experiment reveal attitude towards an advertisement also effects on attitude towards brand. Findings of Brown and Styman [90] also stated that attitudes of the customers in respect of brand may also affect their feeling towards product and buying intentions (Cobb-Walgren et al., [27]). Cobb-Walgren et al., [27] studies also reveal that strong brand equity may lead towards superior brand preferences which in turn effects purchase intention of the customers.

Biehal et al., [91] conducted a research on attitude towards brand and brand choices and his study gave respective findings i.e. attitude towards advertisement in first phase effect feelings towards the product and in the second phase change in attitude towards brand may directly affect the purchase intentions. Another experiment on attitude towards the product and buying intention reveal the result that stated a positive relation between attitude towards product and buying intention (MacKenzie et al.,
[92]).

Muehling et al., [93] performed a print advertisement experiment which gave positive relationship between mindset about the advertisement and attitude toward brand and thus results in positive and significant effect on the purchase intention.

\subsection{Brand Equity}

Shams [94] examined the marketing mix components and brand equity of cell phones in Tehran city. The results reveal strong effect of marketing mix components on brand equity dimensions and positive effects on brand equity.

Yumi et al., [95] investigated the effect of destination image on tourists' destination preference. The results illustrated that affective image and cognition is having positive relation on PPADB.

Lagazian [96] dealt with evaluation of brand equity in hotel management industry. The results reveal that a strong brand is source of long term long-term relationships and thus make the customer's in better position to minimize the perceived level of risks (Berry, [39]).

Zarbi [97] examined the components of marketing mix in relation to the brand equity and its dimensions. Thus brand equity dimensions have positive effect on brand equity and marketing mix.

Chattopadhyay et al., [98] examined the effect of medium mix component on brand equity dimension. The results confirmed that the structural knowledge of two groups i.e. first time buyer and repetitive buyer are expected to be different and thus have difference of information of brand equity.

Hua [99] investigated the influence on brand equity by marketing mix and conclude the results by stating that TV advertisement effect more on brand equity as compared to publishing advertising. Having promotion of the brand too many results in many negative effects on brand equity so promoting brand equity is a complex whole.

Villarejo-Ramos and Sanchez-Franco [100] examined brand equity in terms of marketing communication and sale promotion. Marketing communication recorded positive effect on brand equity and its dimensions.

Keller [28] studied the customer's based brand equity and thus proposed that customer's brand knowledge is the determinant of brand equity.

\subsection{Conclusion}

After reviewing the literature critically, it is evident that product-harm crises negatively affect the brand equity (Dawar, [101]; Klien and Dawar, [57]). Response to product-harm crises play a key role in the development of customers' based brand equity. On the basis of those responses in PHC, customer's holds different level of BE. When PHC started its effect, it leads to ATB of customers. And ATB becomes either positive or negative, depends on the intensity PHC and BA, BL, BI, PQ of that company's product. Literature suggested a little quantity of efforts 
done to examine this framework from different aspects. Still more studies are needed to investigate the relationship of product-harm crisis, attitude towards brand and its effects on brand equity. Building on previous branding research, we have developed a parsimonious model in which consumers' integrate and elaborate product-harm crisis related information. The first study will focus on the effect of product-harm crisis on brand equity, examining the attitude towards brand as a key moderator. The second study will examine the effects of firm response i.e. stone-walling as a component of product-harm crisis related information on customer's based brand equity.

\section{Research Methodology}

Different techniques were used in this present research so that to achieve the desired objectives. All of the methods and techniques are explained in depth in the below section:

\subsection{Universe of the Study}

Universe of this study consists of all the HEC recognized universities of Peshawar District. There are 12 universities (number of public universities 7 and private universities 5) that are operating in Peshawar district according to the updated HEC recognized universities list 2013. Among these universities, 9 are offering business programs which are the population of this study. Among these, three universities were purposively selected. The selected universities were: (1) IMStudies department, University of Peshawar (2) IBMS department, University of Agriculture KPK. (3) Institute of Management Sciences, Peshawar. Due to their goodwill, above mentioned universities were selected.

\subsection{Sampling Design}

Sample design tells us the count of elements to be selected from the given population set. Selecting right sample depends upon experimenter, time frame and availability of resources. Dawar [101] started a research study to examine the "Examination of Nuanced effects of product-harm crises on brand equity" by taking 121 undergraduate business students as sample. Similarly, Niazi et al. [102] investigated the "The Emotionally charged advertisement and their influence on consumers' attitudes" by using a sample of 180 respondents. In the same way, Michelle et al., [103] investigated the "Consumer Responses to Performance Failures by High-Equity Brands" by considering 116 business students.

Keeping in view the time and financial constraints, a sample of 600 undergraduate business students were selected from targeted universities of Peshawar by using Uma Sekran sample selection table on the basis of population size. All these students were selected on purposive sampling technique basis. The reason for using this method of sampling was to get sample of those undergraduates who are using $\mathrm{X}$ laptops. And the reason for using $\mathrm{X}$ Laptop Company is that, $\mathrm{X}$ is the world second bestselling brand of laptop. See Appendix A for the list of top four most selling brands of laptops of the world. Through proportional allocation method (Cochran, 1977), 600 undergraduate business students were selected from two universities. Proportional allocation method is mathematically stated as:

$$
n_{i}=\frac{n}{N} * N_{i}
$$

Where

$\mathrm{n}=$ indicated the required sample size that will be randomly selected from the all sector universities offering business courses.

$N=$ shows the total number of business students enrolled in all sector universities (population size).

$N_{i}=$ no. of business students enrolled in the $\mathrm{i}^{\text {th }}$ selected university.

$n_{i}=$ no. of students to be selected from the $\mathrm{i}^{\text {th }}$ selected university.

Table 3.1. Distribution of sample size in the selected universities

\begin{tabular}{|c|c|c|}
\hline University & $\begin{array}{c}\text { Total } \\
\text { Undergraduate } \\
\text { business students }\end{array}$ & $\begin{array}{c}\text { Sample size of } \\
\text { Undergraduates } \\
\text { Students }\end{array}$ \\
\hline $\begin{array}{c}\text { IBMS, University of } \\
\text { Agriculture Peshawar }\end{array}$ & 400 & 240 \\
\hline $\begin{array}{c}\text { IMStudies, University of } \\
\text { Peshawar }\end{array}$ & 200 & 120 \\
\hline $\begin{array}{c}\text { Institute of Management } \\
\text { Sciences, Peshawar } \\
\text { (est.) }\end{array}$ & 400 & 240 \\
\hline
\end{tabular}

Source: Admission cell.

\subsection{Theoretical Framework}

Fig 3.2 presents the theoretical framework of the current study. The framework shows brand equity as a dependent variable while product harm-crisis as an independent variable and attitude towards brand was taken as moderating variable.

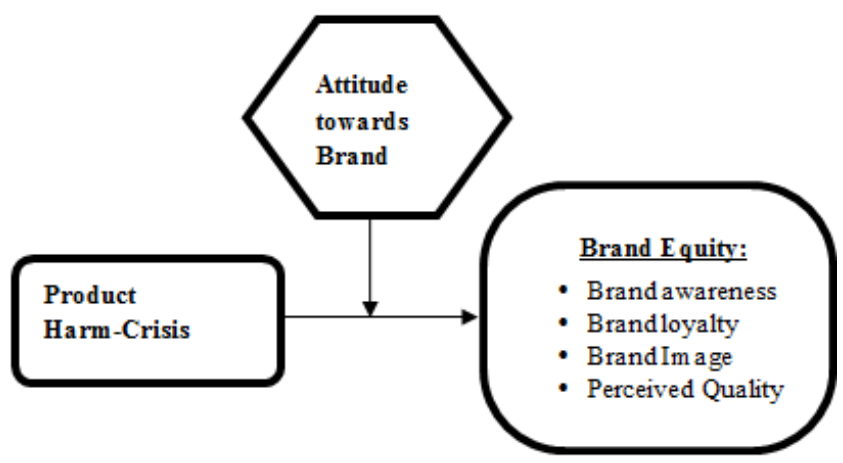

Figure 3.2. Relationship of brand equity with product harm-crisis and attitude towards brand 


\subsubsection{Description of Variables}

Details of each variables of this study were stated below:

\subsubsection{Independent variables}

This study consists of one independent variable i.e. product harm-crisis

\section{Product Harm-Crisis}

Product-harm crises are "multiplex scenarios where products are found to be unsecured, malfunction, or harmful" (Dawar and Pillutla, [3]). Siomkos and Kurzbard [9] studied product-harm crisis as an "sudden pause in the life cycle of the product". Product-harm crises are "disjunctive, trumpet phenomenon wherein products are resulted to be dangerous or defective" (Siomkos and kurzbard, [9]). Shrivastava and Siomkos [44] illustrated the four basic organizational responses in product harm-crisis. (a) Denial/Stonewalling: "the company shows negligence towards consumers' welfare and thus denies responsibility for the harm" and, (b) Involuntary recall: "upon the action of an agency, the company recalls its product" (c) Voluntary recall: "without government agencies intervention, the company chooses to recall its product" and (d) Super effort: "the organization makes effort to depict a responsible image". Respondents were informed about product harm-crisis event by Laptop Company. As laptop is a high involvement product. That's why this study has used Laptop Company as an example of product harm-crisis. Product harm-crises were measured by 3 -items on 5-points Likert scale ranging from strongly disagrees to strongly agree (Dawar and Pillutla, [3]).

This research was useful to examine the effect of a stonewalling response because it has helped to determine a possible boundary condition to the dominance of prior expectations in interpreting objective evidence. Some evidence from research in psychology suggests that faced with evidence which contradicts prior beliefs, individuals tend to discount the evidence and persist in their prior beliefs (Laufer et al., [104]). Managerially, it will be useful to examine the effects of a stonewalling response because such a response is common given that many firms are ill-prepared for crises (Laufer and Coombs, [70]). Secondly it was conducted to determine the effects of stone-walling response in $\mathrm{PHC}$ on $\mathrm{BE}$.

\subsubsection{Dependent Variable}

\section{Brand Equity}

Brand equity is conceptualized multidimensional construct by many brand scholars. Aaker [5] defines brand equity as a value addition that a brand, its name and symbols give to a company's product or service when it is offered to customers.

Aaker [5] introduced four dimensions for the measurement of brand equity: (1) brand awareness, (2) brand loyalty, (3) brand image, and (4) perceived quality.
Brand awareness is the "tendency of the consumers to identify under different situations the company brand" (Keller, [29]). It may be in a form of brand recall and brand recognition. Expectation of a brand in the minds of customers before exposure is termed as brand recognition. When hints are given, consumer can easily recall the brand. Consumers are exposed to several brands at a time but they can recall few of it; sometimes only one brand. Brand awareness was measured on 5-items by using 5-points Likert scale ranging from $1=$ Strongly disagree to $5=$ Strongly agree (Boonghee and Naveen, [106]).

Brand loyalty narrated as a process of behavioral and psychological response function (Jacoby and Kyner, [36]). Brand loyalty was measured on 15 -items by using 5 -points Likert scale ranging from $1=$ strongly disagree to $5=$ strongly agree.

Park et al., [40] stated that brand image as getting customer's attention in order to have some positive image in the minds of customers. Aaker [5], defined brand image as a organizing association in some considerable way. Brand Image was measured on 21-items by using 5-points Likert scale ranging from $1=$ Strongly disagree to $5=$ Strongly agree.

Kotler and Keller [1] defined perceived quality as "The ability of product to fulfill consumer's presumptions". There were 7- items for measuring perceived quality by using 5-points Likert scale ranging from $1=$ Strongly disagree to $5=$ Strongly agree (Ziethaml, [107]).

\subsubsection{Moderating Variable}

Attitude towards brand

Fishbein and Ajzen [16], in agreement with Kanouse [17], suggested that attitude is degree of favor or resistance towards some object". Mitchell and Olson [24] define attitude toward the brand as an "individual's internal analysis of the brand." Attitude towards brand was measured on 3-items on 7-points Likert scale (Very bad-Very good, Very negative- Very positive, Very bad quality- Very good quality).

\subsubsection{Data Collection}

The data were collected by manipulating the newspaper ads that states the PHC of X laptops. Initially stimuli were presented in the form, recently dated newspaper article that has reported the product-harm crisis provoke event. The self-designed newspaper article has described that laptop (X Laptop company) has caused following product harm-crises: (a) battery of laptop get burst and had caused several causalities (b) laptop screen caused severe eye vision problems (c) even laptop caused some injuries as well due to battery burst. After reading the newspaper article, subjects were asked to respond to the designed questionnaire in classroom setting.

Then another self-designed newspaper article was displayed to the same respondents; stating the stonewalling 
response of the X laptop company i.e. X Laptop Company avoiding to accept their mistake. Even take no actions like product recall, apology or reintroduction. After reading this article, the attitude of respondents towards $\mathrm{X}$ brand was evaluated and also its effect of such response by X Laptop company on the brand equity of respondents.

Both questionnaires are provided in Appendix-B.

\subsection{Data Analysis}

SPSS v.20 was utilized to analyze the collected data. The outcomes were calculated in terms of counts, percentages and mean average score (MAS). The MAS was computed by taking the weighted mean of each and every item of a particular variable by taking the frequency of each category of 5-points and 7-points Likert's Scale as weight.

To test the effect of product harm-crisis on the customer's brand equity, and to investigate the moderating effect of attitude towards brand (ATB) on the customer's based brand equity, a technique of regression analysis was applied. The following three regression models were applied to gain insight in to the problem under investigation.

To test the hypothesis mentioned above, the following regression models was fitted by using ordinary least square (OLS) method.

$$
\mathrm{BE}=\beta 0+\beta 1 \mathrm{PHC}+\varepsilon
$$

The regression model mentioned in equation (3.3) has tested the effect of product harm-crisis (PHC) on the customer's based brand equity (BE). Similarly, the interaction effect of product harm crisis and attitude towards brand $(\mathrm{PHC} \times \mathrm{ATB})$ was tested by using model (3.5).

$$
\mathrm{BE}=\beta 0+\beta 1 \mathrm{PHC}+\beta 2 \mathrm{ATB}+\beta 3(\mathrm{PHC} \times \mathrm{ATB})+\varepsilon
$$

In order to test the significant difference between the average perception of customers regarding product harm-crisis before and after stone-willing response, Wilcoxon signed-ranked test was used. As data were not assume to be normally distributed. It is a non-parametric statistical hypothesis test. It is represented by W. Below is the formula for calculation of test statistic W

$$
W=\left|\sum_{i=1}^{N_{r}}\left[\operatorname{sgn}\left(x_{2, i}-x_{1, i}\right) \cdot R_{i}\right]\right|
$$

Where $\mathrm{N}$ be the sample size, the number of pairs. For $\mathrm{i}=$ $1, \ldots, \mathrm{N}$

Where $\mathrm{N}$ be the sample size, the number of pairs. For $i=$ $1, \ldots, \mathrm{N}$

For $N_{r} \geq 10$, a $\quad$ Z-score can be calculated

$$
\text { As } z=\frac{W-0.5}{\sigma_{W}}, \sigma_{W}=\sqrt{\frac{N_{r}\left(N_{r}+1\right)\left(2 N_{r}+1\right)}{6}} \text {. }
$$

If $z>z_{\text {critical }}$ then reject $H_{0}$

For $N_{r}<10, W$ is compared to a critical value from a reference table

If $W \geq W_{\text {critical }, N_{r}}$ then reject $H_{0}$

Alternatively, a p-value can be calculated from enumeration of all possible combinations of Wgiven $\mathrm{Nr}$.

\section{Results and Discussions}

This study investigated the effect of product-harm crisis on customer's based brand equity and the moderating role of attitude towards brand.

\subsection{Reliability Analysis}

The conclusions of reliability analysis were elaborated in the table 4.1. In order to test the reliability of multiple-item scales, Coefficient alpha $(\alpha)$ was applied. It shows the internal consistency for multiple-item scale. Alpha values show either different item coincides or not. Cronbach's alpha value range between 0 and 1 , close to 0 means no consistency while close to 1 means complete consistency. Usually value above than 0.6 is considered as reliable (Hair et al., [108]).

Table 4.1. Reliability Measurement of variables under study

\begin{tabular}{|c|c|c|}
\hline Variable & Cronbach's alpha & Remarks \\
\hline Product-harm crisis & 0.740 & Reliable \\
\hline Brand Equity & 0.733 & Reliable \\
\hline Attitude towards brand & 0.738 & Reliable \\
\hline
\end{tabular}

\subsection{Distribution of Respondents in Regards with PHC:}

This portion of the chapter explains the respondent's responses to all the attributes. The figures shown in table 4.2 explain the responses of the respondents in the PHC. The responses in the below table illustrates that the majority of responses laid in the fourth and fifth category on the likert-scale. The outcomes of the items 1,2 and 3 explain the negative effect of PHC on respondents feeling as the mean average score (MAS) is greater than 3 . In all of their statements about PHC, the highest MAS (4.7700) are recorded for the risk attached with the purchase and use of PHC products. This continuation is followed by the item no. 1 with MAS of (4.0800) and item no.3 with MAS of (4.0700) that illustrates the feelings of respondents regarding negative news as well as product quality failure. It shows that in general when negative news is spread; it has negative effects on the feelings of the customers. 
Table 4.2. Distribution of respondents in regards with Product-harm crisis

\begin{tabular}{|c|c|c|c|c|c|c|c|}
\hline \multirow{2}{*}{ S. No } & \multirow{2}{*}{ Items } & \multicolumn{5}{|c|}{ Product-harm crisis } & \multirow{2}{*}{ MAS } \\
\hline & & 1 & 2 & 3 & 4 & 5 & \\
\hline 1 & I feel the negative news reports about $X$ laptop serious. & $\begin{array}{c}6 \\
(1.0) \\
\end{array}$ & $\begin{array}{c}0 \\
(0.0)\end{array}$ & $\begin{array}{c}6 \\
(2.0) \\
\end{array}$ & $\begin{array}{l}516 \\
(88)\end{array}$ & $\begin{array}{c}72 \\
(100)\end{array}$ & 4.0800 \\
\hline 2 & $\begin{array}{c}\text { The news reports about } \mathrm{X} \text { make me feel that its } \mathrm{X} \text { laptops are involved with many } \\
\text { risks. }\end{array}$ & $\begin{array}{c}24 \\
(4.0)\end{array}$ & $\begin{array}{c}0 \\
(0.0)\end{array}$ & $\begin{array}{c}12 \\
(6.0)\end{array}$ & $\begin{array}{c}18 \\
(9.0)\end{array}$ & $\begin{array}{c}546 \\
(100.0)\end{array}$ & 4.7700 \\
\hline \multirow[t]{2}{*}{3} & I feel that the negative news reports truly reveal the quality problems of $\mathrm{X}$ laptop. & $\begin{array}{c}0 \\
(0.0)\end{array}$ & $\begin{array}{c}0 \\
(0.0)\end{array}$ & $\begin{array}{c}6 \\
(1.0)\end{array}$ & $\begin{array}{c}546 \\
(92.0)\end{array}$ & $\begin{array}{c}48 \\
(100.0)\end{array}$ & 4.0700 \\
\hline & Overall Mean & & & & & & 4.3067 \\
\hline
\end{tabular}

$1=$ strongly disagree, $2=$ disagree, $3=$ neutral, $4=$ agree, $5=$ strongly agree; MAS $=$ mean average score

\subsection{Distribution of Respondents in Regards with Brand Equity}

\subsubsection{Distribution of Respondents in Regards with Brand Awareness}

The figures given in the following table 4.3 illustrates responses of the respondents towards BA. There are five items of BA which are measured on five point's likert-scale. MAS of item no. 2 are (4.9600) which are the highest MAS in all of the five items. As MAS of all items are greater than 3, it shows that all responses are laying the category of 4 and 5 on likert-scale i.e. agree and strongly agree. Item no. 2 illustrates the awareness of the respondents regarding X brand of laptop. The second highest mean average score is of item no. 1, which explains the recognition of brand in the mind $\mathrm{s}$ of respondents as compare to other competing brands with MAS of (4.9100). The lowest value of MAS is (4.3000) for item no. 4 which is still greater than 3 , thus illustrates that respondents can easily and quickly recall brand logo and symbol among other competing brands. Overall the brand awareness of the respondents is very high and only few of the responses laid in category 1 and 3 on the likert-scale.

Table 4.3. Distribution of respondents in regards with Brand Awareness

\begin{tabular}{|c|c|c|c|c|c|c|c|}
\hline \multirow{2}{*}{ S. No } & \multirow{2}{*}{ Items } & \multicolumn{5}{|c|}{ Brand Awareness } & \multirow{2}{*}{ MAS } \\
\hline & & 1 & 2 & 3 & 4 & 5 & \\
\hline 1 & I can recognize $\mathrm{X}$ Laptop among other competing brands & $\begin{array}{c}6 \\
(1.0)\end{array}$ & $\begin{array}{c}0 \\
(0.0)\end{array}$ & $\begin{array}{c}12 \\
(3.0)\end{array}$ & $\begin{array}{c}6 \\
(4.0)\end{array}$ & $\begin{array}{c}576 \\
(100.0)\end{array}$ & 4.9100 \\
\hline 2 & I am aware of X Laptop. & $\begin{array}{c}0 \\
(0.0)\end{array}$ & $\begin{array}{c}0 \\
(0.0)\end{array}$ & $\begin{array}{c}12 \\
(2.0)\end{array}$ & $\begin{array}{c}0 \\
(0.0)\end{array}$ & $\begin{array}{c}588 \\
(100.0)\end{array}$ & 4.9600 \\
\hline 3 & Some characteristics of X Laptop come to my mind quickly. & $\begin{array}{c}0 \\
(0.0)\end{array}$ & $\begin{array}{c}0 \\
(0.0)\end{array}$ & $\begin{array}{c}18 \\
(3.0)\end{array}$ & $\begin{array}{c}12 \\
(7.0)\end{array}$ & $\begin{array}{c}556 \\
(100.0)\end{array}$ & 4.9000 \\
\hline 4 & I can quickly recall the symbol or logo of X Laptop. & $\begin{array}{c}0 \\
(0.0)\end{array}$ & $\begin{array}{c}0 \\
(0.0)\end{array}$ & $\begin{array}{c}30 \\
(5.0)\end{array}$ & $\begin{array}{c}360 \\
(65.0)\end{array}$ & $\begin{array}{c}210 \\
(100.0)\end{array}$ & 4.3000 \\
\hline \multirow[t]{2}{*}{5} & I have no difficulty in imagining $\mathrm{X}$ Laptop in my mind. & $\begin{array}{c}0 \\
(0.0)\end{array}$ & $\begin{array}{c}0 \\
(0.0)\end{array}$ & $\begin{array}{c}0 \\
(0.0)\end{array}$ & $\begin{array}{c}78 \\
(13.0)\end{array}$ & $\begin{array}{c}522 \\
(100.0)\end{array}$ & 4.8700 \\
\hline & Overall Mean & & & & & & 4.788 \\
\hline
\end{tabular}

$1=$ strongly disagree, $2=$ disagree, $3=$ neutral, $4=$ agree, $5=$ strongly agree; MAS $=$ mean average score

\subsubsection{Distribution of Respondents in Regards with Brand Loyalty}

The figures given in the table 4.4 illustrates BL responses of the respondents. The responses were measured on the five likert-scales. The MAS of item no. 10 is greater than 3 i.e. (3.1300) which are representing weak feeling of loyalty to brand that respondents are willing to recommend the given brand to other people. The lowest MAS is of item no. 15 which illustrates that respondents will not buy the same brand after getting PHC news if product is made available in same stores again. On ward items no. 9, 11, 2, 14 and 13 mean average scores illustrates in general that respondents will never recommend this brand as well as never place this brand in the prior selection choice list. Overall MAS are below 3 which means that responses are mostly lying in strongly disagree and disagree zone. Thus brand loyalty is negatively affected by PHC. 
Table 4.4. Distribution of respondents in regards with Brand Loyalty

\begin{tabular}{|c|c|c|c|c|c|c|c|}
\hline \multirow{2}{*}{ S. No } & \multirow{2}{*}{ Item } & \multicolumn{5}{|c|}{ Brand Loyalty } & \multirow{2}{*}{ MAS } \\
\hline & & 1 & 2 & 3 & 4 & 5 & \\
\hline 1 & I intend to buy this brand in the near future. & $\begin{array}{c}96 \\
(16.0) \\
\end{array}$ & $\begin{array}{c}504 \\
(84.0) \\
\end{array}$ & $\begin{array}{c}0 \\
(0.0) \\
\end{array}$ & $\begin{array}{c}0 \\
(0.0) \\
\end{array}$ & $\begin{array}{c}0 \\
(0.0) \\
\end{array}$ & 1.8400 \\
\hline 3 & I consider this brand as my first choice in this category. & $\begin{array}{c}48 \\
(8.0) \\
\end{array}$ & $\begin{array}{c}552 \\
(92.0) \\
\end{array}$ & $\begin{array}{c}0 \\
(0.0)\end{array}$ & $\begin{array}{c}0 \\
(0.0) \\
\end{array}$ & $\begin{array}{c}0 \\
(0.0)\end{array}$ & 1.9200 \\
\hline 4 & I will buy the same brand, the next time I need that product. & $\begin{array}{c}156 \\
(26.0) \\
\end{array}$ & $\begin{array}{c}438 \\
(73.0) \\
\end{array}$ & $\begin{array}{c}6 \\
(1.0)\end{array}$ & $\begin{array}{c}0 \\
(0.0)\end{array}$ & $\begin{array}{c}0 \\
(0.0)\end{array}$ & 1.7500 \\
\hline 5 & I will continue to be loyal customer for this brand. & $\begin{array}{c}450 \\
(75.0)\end{array}$ & $\begin{array}{c}138 \\
(23.0)\end{array}$ & $\begin{array}{c}12 \\
(2.0)\end{array}$ & $\begin{array}{c}0 \\
(0.0)\end{array}$ & $\begin{array}{c}0 \\
(0.0)\end{array}$ & 1.2700 \\
\hline 6 & $\begin{array}{c}\text { I am willing to pay a price premium over competing products to be able to purchase this } \\
\text { brand again. }\end{array}$ & $\begin{array}{c}522 \\
(87.0)\end{array}$ & $\begin{array}{c}72 \\
(12.0)\end{array}$ & $\begin{array}{c}6 \\
(1.0)\end{array}$ & $\begin{array}{c}0 \\
(0.0)\end{array}$ & $\begin{array}{c}0 \\
(0.0)\end{array}$ & 1.1400 \\
\hline 7 & I would only consider purchasing this brand again, if it would be substantially cheaper. & $\begin{array}{c}30 \\
(5.0)\end{array}$ & $\begin{array}{c}228 \\
(38.0)\end{array}$ & $\begin{array}{c}306 \\
(51.0)\end{array}$ & $\begin{array}{c}36 \\
(6.0)\end{array}$ & $\begin{array}{c}0 \\
(0.0)\end{array}$ & 2.5800 \\
\hline 8 & I say positive things about this brand to other people. & $\begin{array}{c}6 \\
(1.0)\end{array}$ & $\begin{array}{c}582 \\
(97.0)\end{array}$ & $\begin{array}{c}12 \\
(2.0)\end{array}$ & $\begin{array}{c}0 \\
(0.0)\end{array}$ & $\begin{array}{c}0 \\
(0.0)\end{array}$ & 2.0100 \\
\hline 9 & I recommend this brand to someone who seeks my advice. & $\begin{array}{c}594 \\
(99.0)\end{array}$ & $\begin{array}{c}0 \\
(0.0)\end{array}$ & $\begin{array}{c}6 \\
(1.0)\end{array}$ & $\begin{array}{c}0 \\
(0.0)\end{array}$ & $\begin{array}{c}0 \\
(0.0)\end{array}$ & 1.0200 \\
\hline 10 & I intend to recommend this brand to other people. & $\begin{array}{c}12 \\
(2.0)\end{array}$ & $\begin{array}{c}174 \\
(29.0)\end{array}$ & $\begin{array}{c}138 \\
(23.0)\end{array}$ & $\begin{array}{c}276 \\
(46.0)\end{array}$ & $\begin{array}{c}0 \\
(0.0)\end{array}$ & 3.1300 \\
\hline 11 & I consider this brand my first choice in the next few years. & $\begin{array}{c}594 \\
(99.0)\end{array}$ & $\begin{array}{c}0 \\
(0.0)\end{array}$ & $\begin{array}{c}0 \\
(0.0)\end{array}$ & $\begin{array}{c}6 \\
(2.0)\end{array}$ & $\begin{array}{c}0 \\
(0.0)\end{array}$ & 1.0300 \\
\hline 12 & I get good value for my money. & $\begin{array}{c}306 \\
(51.0)\end{array}$ & $\begin{array}{c}294 \\
(49.0)\end{array}$ & $\begin{array}{c}0 \\
(0.0)\end{array}$ & $\begin{array}{c}0 \\
(0.0)\end{array}$ & $\begin{array}{c}0 \\
(0.0)\end{array}$ & 1.4900 \\
\hline 13 & I consider myself to be loyal to X Laptop. & $\begin{array}{c}564 \\
(94.0)\end{array}$ & $\begin{array}{c}90 \\
(5.0)\end{array}$ & $\begin{array}{l}18 \\
(1.0)\end{array}$ & $\begin{array}{c}0 \\
(0.0)\end{array}$ & $\begin{array}{c}0 \\
(0.0)\end{array}$ & 1.0700 \\
\hline 14 & X Laptop would be my first choice. & $\begin{array}{c}564 \\
(94.0)\end{array}$ & $\begin{array}{c}36 \\
(6.0)\end{array}$ & $\begin{array}{c}0 \\
(0.0)\end{array}$ & $\begin{array}{c}0 \\
(0.0)\end{array}$ & $\begin{array}{c}0 \\
(0.0)\end{array}$ & 1.0600 \\
\hline 15 & I will not buy other brands if X Laptop is available at the same store. & $\begin{array}{c}600 \\
(100.0)\end{array}$ & $\begin{array}{c}0 \\
(0.0)\end{array}$ & $\begin{array}{c}0 \\
(0.0)\end{array}$ & $\begin{array}{c}0 \\
(0.0)\end{array}$ & $\begin{array}{c}0 \\
(0.0)\end{array}$ & 1.0000 \\
\hline & Overall Mean & & & & & & 1.5566 \\
\hline
\end{tabular}

$1=$ strongly disagree, 2 = disagree, $3=$ neutral, $4=$ agree, $5=$ strongly agree; MAS $=$ mean average score

\subsubsection{Distribution of Respondents in Regards with Brand Image:}

The figures in the below table describes the responses of respondents in term of BI. The item no. 1 is having highest MAS of (4.9000) which illustrates that respondents are having very clear understanding of given brand. The item no.2 and 15 showing MAS values of 4.8500 and 4.1000 which explains the responses of respondents that the shows strong affiliation towards brand and they wish to purchase new products of it if company launch some new products of it. The items no. 18, 20, 11, 6 and13 are showing lowest MAS. Thus illustrates that respondent's perception of product's quality and its advantages are quite low. Which means they are somewhat strongly disagree about the quality of the product as well as its advantages. The item no.14 is showing MAS of (3.2100) which explains respondent's responses somewhat neutral about the leading brand of market i.e. $\mathrm{X}$ is a leading brand in the market. The overall MAS of items are below 3 which states that brand image of brand is also get affected by PHC. 
Table 4.5. Distribution of respondents in regards with Brand Image

\begin{tabular}{|c|c|c|c|c|c|c|c|}
\hline \multirow{2}{*}{ S. No } & \multirow{2}{*}{ Items } & \multicolumn{5}{|c|}{ Brand Image } & \multirow{2}{*}{ MAS } \\
\hline & & 1 & 2 & 3 & 4 & 5 & \\
\hline 1 & I have a clear understanding on this brand. & $\begin{array}{c}0 \\
(0.0) \\
\end{array}$ & $\begin{array}{c}0 \\
(0.0) \\
\end{array}$ & $\begin{array}{c}0 \\
(0.0) \\
\end{array}$ & $\begin{array}{c}60 \\
(10.0) \\
\end{array}$ & $\begin{array}{c}540 \\
(90.0) \\
\end{array}$ & 4.9000 \\
\hline 2 & Symbol of the brand can build recognition to me. & $\begin{array}{c}6 \\
(1.0) \\
\end{array}$ & $\begin{array}{c}0 \\
(0.0) \\
\end{array}$ & $\begin{array}{c}6 \\
(1.0) \\
\end{array}$ & $\begin{array}{c}54 \\
(9.0) \\
\end{array}$ & $\begin{array}{c}534 \\
(89.0) \\
\end{array}$ & 4.8500 \\
\hline 3 & $\mathrm{X}$ Laptop comes to my mind at first when mentions laptop companies. & $\begin{array}{c}18 \\
(3.0)\end{array}$ & $\begin{array}{c}582 \\
(97.0)\end{array}$ & $\begin{array}{c}0 \\
(0.0)\end{array}$ & $\begin{array}{c}0 \\
(0.0) \\
\end{array}$ & $\begin{array}{c}0 \\
(0.0)\end{array}$ & 1.9700 \\
\hline 4 & I like X Laptop very much. & $\begin{array}{c}264 \\
(44.0)\end{array}$ & $\begin{array}{c}336 \\
(56.0)\end{array}$ & $\begin{array}{c}0 \\
(0.0) \\
\end{array}$ & $\begin{array}{c}0 \\
(0.0) \\
\end{array}$ & $\begin{array}{c}0 \\
(0.0) \\
\end{array}$ & 1.5600 \\
\hline 5 & I am satisfied with $X$ laptop quality. & $\begin{array}{c}90 \\
(15.0) \\
\end{array}$ & $\begin{array}{c}504 \\
(84.0) \\
\end{array}$ & $\begin{array}{c}6 \\
(1.0) \\
\end{array}$ & $\begin{array}{c}0 \\
(0.0) \\
\end{array}$ & $\begin{array}{c}0 \\
(0.0) \\
\end{array}$ & 1.8600 \\
\hline 6 & The product quality of the brand is good. & $\begin{array}{c}372 \\
(62.0) \\
\end{array}$ & $\begin{array}{c}222 \\
(37.0) \\
\end{array}$ & $\begin{array}{c}0 \\
(0.0) \\
\end{array}$ & $\begin{array}{c}0 \\
(0.0) \\
\end{array}$ & $\begin{array}{c}6 \\
(1.0) \\
\end{array}$ & 1.4100 \\
\hline 7 & I recognize this brand when I have a need of laptop. & $\begin{array}{c}6 \\
(1.0)\end{array}$ & $\begin{array}{c}570 \\
(95.0)\end{array}$ & $\begin{array}{c}24 \\
(4.0)\end{array}$ & $\begin{array}{c}0 \\
(0.0)\end{array}$ & $\begin{array}{c}0 \\
(0.0)\end{array}$ & 2.0300 \\
\hline 8 & The brand image is outstanding and gives me a good impression. & $\begin{array}{c}36 \\
(6.0)\end{array}$ & $\begin{array}{c}132 \\
(22.0)\end{array}$ & $\begin{array}{c}432 \\
(72.0)\end{array}$ & $\begin{array}{c}0 \\
(0.0) \\
\end{array}$ & $\begin{array}{c}0 \\
(0.0)\end{array}$ & 2.6600 \\
\hline 9 & The values of this brand give me confidence to its products. & $\begin{array}{c}510 \\
(85.0) \\
\end{array}$ & $\begin{array}{c}84 \\
(14.0) \\
\end{array}$ & $\begin{array}{c}6 \\
(1.0) \\
\end{array}$ & $\begin{array}{c}0 \\
(0.0) \\
\end{array}$ & $\begin{array}{c}0 \\
(0.0) \\
\end{array}$ & 1.1600 \\
\hline 10 & The product attributes can fulfill my functional and emotional needs. & $\begin{array}{c}294 \\
(49.0)\end{array}$ & $\begin{array}{c}300 \\
(50.0)\end{array}$ & $\begin{array}{c}6 \\
(1.0)\end{array}$ & $\begin{array}{c}0 \\
(0.0)\end{array}$ & $\begin{array}{c}0 \\
(0.0)\end{array}$ & 1.5200 \\
\hline 11 & I can specifically point out X laptop's advantages. & $\begin{array}{c}294 \\
(49.0) \\
\end{array}$ & $\begin{array}{c}300 \\
(50.0) \\
\end{array}$ & $\begin{array}{c}6 \\
(2.0) \\
\end{array}$ & $\begin{array}{c}0 \\
(0.0) \\
\end{array}$ & $\begin{array}{c}0 \\
(0.0) \\
\end{array}$ & 1.1200 \\
\hline 12 & Use of this brand can express my personality. & $\begin{array}{c}36 \\
(6.0) \\
\end{array}$ & $\begin{array}{c}92 \\
(17.0) \\
\end{array}$ & $\begin{array}{c}414 \\
(69.0) \\
\end{array}$ & $\begin{array}{c}48 \\
(8.0) \\
\end{array}$ & $\begin{array}{c}0 \\
(0.0) \\
\end{array}$ & 2.7900 \\
\hline 13 & This brand provides a variety of products. & $\begin{array}{c}534 \\
(89.0) \\
\end{array}$ & $\begin{array}{c}42 \\
(7.0) \\
\end{array}$ & $\begin{array}{c}18 \\
(3.0) \\
\end{array}$ & $\begin{array}{c}6 \\
(1.0) \\
\end{array}$ & $\begin{array}{c}0 \\
(0.0) \\
\end{array}$ & 1.1600 \\
\hline 14 & This is the leading brand in the market. & $\begin{array}{c}6 \\
(1.0) \\
\end{array}$ & $\begin{array}{c}30 \\
(5.0) \\
\end{array}$ & $\begin{array}{c}396 \\
(66.0) \\
\end{array}$ & $\begin{array}{c}168 \\
(28.0) \\
\end{array}$ & $\begin{array}{c}0 \\
(0.0) \\
\end{array}$ & 3.2100 \\
\hline 15 & I will purchase when X laptop will launch new product. & $\begin{array}{c}24 \\
(4.0) \\
\end{array}$ & $\begin{array}{c}6 \\
(1.0) \\
\end{array}$ & $\begin{array}{c}6 \\
(1.0) \\
\end{array}$ & $\begin{array}{c}414 \\
(69.0) \\
\end{array}$ & $\begin{array}{c}150 \\
(25.0) \\
\end{array}$ & 4.1000 \\
\hline 16 & $\mathrm{X}$ Laptop is different from other laptops. & $\begin{array}{c}498 \\
(83.0) \\
\end{array}$ & $\begin{array}{c}72 \\
(12.0) \\
\end{array}$ & $\begin{array}{c}18 \\
(3.0) \\
\end{array}$ & $\begin{array}{c}0 \\
(0.0) \\
\end{array}$ & $\begin{array}{c}12 \\
(2.0) \\
\end{array}$ & 1.2600 \\
\hline 17 & $\mathrm{X}$ Laptop is my first choice. & $\begin{array}{c}18 \\
(3.0) \\
\end{array}$ & $\begin{array}{c}66 \\
(11.0) \\
\end{array}$ & $\begin{array}{c}546 \\
(80.0) \\
\end{array}$ & $\begin{array}{c}36 \\
(6.0) \\
\end{array}$ & $\begin{array}{c}0 \\
(0.0) \\
\end{array}$ & 2.8900 \\
\hline 18 & I am satisfy with this brand but will try other brand next time. & $\begin{array}{c}546 \\
(91.0)\end{array}$ & $\begin{array}{c}54 \\
(9.0)\end{array}$ & $\begin{array}{c}0 \\
(0.0) \\
\end{array}$ & $\begin{array}{c}0 \\
(0.0) \\
\end{array}$ & $\begin{array}{c}0 \\
(0.0) \\
\end{array}$ & 1.0900 \\
\hline 19 & I am pleased to repurchase this brand. & $\begin{array}{c}288 \\
(48.0) \\
\end{array}$ & $\begin{array}{c}288 \\
(48.0) \\
\end{array}$ & $\begin{array}{c}6 \\
(1.0) \\
\end{array}$ & $\begin{array}{c}18 \\
(3.0) \\
\end{array}$ & $\begin{array}{c}0 \\
(0.0) \\
\end{array}$ & 1.5900 \\
\hline 20 & I will buy X laptop even no advertisement. & $\begin{array}{c}546 \\
(91.0) \\
\end{array}$ & $\begin{array}{c}48 \\
(8.0) \\
\end{array}$ & $\begin{array}{c}6 \\
(1.0) \\
\end{array}$ & $\begin{array}{c}0 \\
(0.0) \\
\end{array}$ & $\begin{array}{c}0 \\
(0.0) \\
\end{array}$ & 1.1000 \\
\hline 21 & I will insist on buying $\mathrm{X}$ laptop even other new laptops are launched. & $\begin{array}{c}92 \\
(17.0) \\
\end{array}$ & $\begin{array}{c}402 \\
(67.0) \\
\end{array}$ & $\begin{array}{c}96 \\
(16.0) \\
\end{array}$ & $\begin{array}{c}0 \\
(0.0) \\
\end{array}$ & $\begin{array}{c}0 \\
(0.0) \\
\end{array}$ & 1.9900 \\
\hline & Overall Mean & & & & & & 2.2000 \\
\hline
\end{tabular}

$1=$ strongly disagree, $2=$ disagree, $3=$ neutral, $4=$ agree, $5=$ strongly agree; MAS $=$ mean average score

\subsubsection{Distribution of Respondents in Regards with Perceived Quality}

The below table show the percentage results of seven items of PQ. Item no.6 is having the highest MAS of (4.12000) which illustrates that X appears to be of very poor quality after PHC news. Respondents are having negative opinions about the perceived quality of product. Item no. 3 is having the next highest MAS i.e. 3.97000 which is higher than 3 . Thus illustrates that near to neutral response, most of the respondents agree about the probability that $X$ laptop would be functional is very high. But after the stone walling response from the company, the results about the functionality of the product are quite negative. Item no. 7 is showing the lowest MAS of (2.0400) which illustrate that X don't appear to be of very poor quality. 
Table 4.6. Distribution of respondents in regards with Perceived Quality

\begin{tabular}{|c|c|c|c|c|c|c|c|}
\hline \multirow{2}{*}{ S. No } & \multirow{2}{*}{ Items } & \multicolumn{5}{|c|}{ Perceived Quality } & \multirow{2}{*}{ MAS } \\
\hline & & 1 & 2 & 3 & 4 & 5 & \\
\hline 1 & $\mathrm{X}$ laptop is of high quality. & $\begin{array}{c}0 \\
(0.0)\end{array}$ & $\begin{array}{c}60 \\
(10.0)\end{array}$ & $\begin{array}{c}66 \\
(11.0)\end{array}$ & $\begin{array}{c}474 \\
(79.0)\end{array}$ & $\begin{array}{c}0 \\
(0.0)\end{array}$ & 3.6900 \\
\hline 2 & The likely quality of $\mathrm{X}$ laptop is extremely high. & $\begin{array}{c}0 \\
(0.0)\end{array}$ & $\begin{array}{c}96 \\
(16.0)\end{array}$ & $\begin{array}{c}504 \\
(84.0)\end{array}$ & $\begin{array}{c}0 \\
(0.0)\end{array}$ & $\begin{array}{c}0 \\
(0.0)\end{array}$ & 2.8400 \\
\hline 3 & The likelihood that $\mathrm{X}$ laptop would be functional is very high. & $\begin{array}{c}0 \\
(0.0)\end{array}$ & $\begin{array}{c}0 \\
(0.0)\end{array}$ & $\begin{array}{c}18 \\
(3.0)\end{array}$ & $\begin{array}{c}582 \\
(97.0)\end{array}$ & $\begin{array}{c}0 \\
(0.0)\end{array}$ & 3.9700 \\
\hline 4 & $\mathrm{X}$ laptop appears to be reliable. & $\begin{array}{c}6 \\
(1.0)\end{array}$ & $\begin{array}{c}180 \\
(30.0)\end{array}$ & $\begin{array}{c}24 \\
(4.0)\end{array}$ & $\begin{array}{c}390 \\
(65.0)\end{array}$ & $\begin{array}{c}0 \\
(0.0)\end{array}$ & 3.3300 \\
\hline 5 & $\mathrm{X}$ Laptop must be of very good quality. & $\begin{array}{c}54 \\
(9.0) \\
\end{array}$ & $\begin{array}{c}108 \\
(18.0)\end{array}$ & $\begin{array}{c}18 \\
(3.0) \\
\end{array}$ & $\begin{array}{c}528 \\
(69.0) \\
\end{array}$ & $\begin{array}{c}6 \\
(1.0) \\
\end{array}$ & 3.3500 \\
\hline 6 & $\mathrm{X}$ Laptop appears to be of very poor quality. & $\begin{array}{c}0 \\
(0.0)\end{array}$ & $\begin{array}{c}0 \\
(0.0)\end{array}$ & $\begin{array}{c}0 \\
(0.0)\end{array}$ & $\begin{array}{c}528 \\
(88.0)\end{array}$ & $\begin{array}{c}72 \\
(12.0)\end{array}$ & 4.1200 \\
\hline \multirow[t]{2}{*}{7} & X Laptop not appears to be of very poor quality. & $\begin{array}{c}582 \\
(98.0) \\
\end{array}$ & $\begin{array}{c}0 \\
(0.0) \\
\end{array}$ & $\begin{array}{c}0 \\
(0.0) \\
\end{array}$ & $\begin{array}{c}12 \\
(2.0) \\
\end{array}$ & $\begin{array}{c}0 \\
(0.0) \\
\end{array}$ & 2.0400 \\
\hline & Overall Mean & & & & & & 3.334 \\
\hline
\end{tabular}

$1=$ strongly disagree, $2=$ disagree, $3=$ neutral, $4=$ agree, $5=$ strongly agree; MAS $=$ mean average score

\subsection{Distribution of Respondents in Regards with Attitude towards Brand}

The figures in the below table illustrates the responses of respondents towards ATB. All items in ATB table are below than 3 which illustrates that overall respondents responses towards ATB are near to very bad and bad category in seven scale likert-scales. Item no. 1 is having MAS of (1.6400) which explains that respondent's general opinion of X is very bad and bad. Whereas item no. 3 is having MAS of (1.7300) which illustrates that respondents overall view of $X$ is very negative and negative. Also MAS of (2.5000) of item no.2 shows that respondents feeling of overall X brand is bad and somewhat bad. In general, when PHC news about product gets spread, it will show some negative attitude of respondents towards that brand.

Table 4.7. Distribution of respondents in regards with Attitude towards Brand

\begin{tabular}{|c|c|c|c|c|c|c|c|c|c|}
\hline \multirow{2}{*}{ S. No } & \multirow{2}{*}{ Items } & & & \multicolumn{5}{|c|}{ Attitude Towards Brand } & \multirow{2}{*}{ MAS } \\
\hline & & 1 & 2 & 3 & 4 & 5 & 6 & 7 & \\
\hline 1 & My general opinion of X Laptop is: & $\begin{array}{c}228 \\
(38.0)\end{array}$ & $\begin{array}{c}366 \\
(61.0)\end{array}$ & $\begin{array}{c}0 \\
(0.0)\end{array}$ & $\begin{array}{c}6 \\
(1.0)\end{array}$ & $\begin{array}{c}0 \\
(0.0)\end{array}$ & $\begin{array}{c}0 \\
(0.0)\end{array}$ & $\begin{array}{c}0 \\
(0.0)\end{array}$ & 1.6400 \\
\hline 2 & I feel that overall, $\mathrm{X}$ Laptop is: & $\begin{array}{c}90 \\
(15.0) \\
\end{array}$ & $\begin{array}{c}120 \\
(20.0) \\
\end{array}$ & $\begin{array}{c}390 \\
(65.0) \\
\end{array}$ & $\begin{array}{c}0 \\
(0.0) \\
\end{array}$ & $\begin{array}{c}0 \\
(0.0) \\
\end{array}$ & $\begin{array}{c}0 \\
(0.0) \\
\end{array}$ & $\begin{array}{c}0 \\
(0.0) \\
\end{array}$ & 2.5000 \\
\hline 3 & My overall view of $\mathrm{X}$ Laptop is: & $\begin{array}{c}174 \\
(29.0)\end{array}$ & $\begin{array}{c}474 \\
(69.0)\end{array}$ & $\begin{array}{c}12 \\
(2.0)\end{array}$ & $\begin{array}{c}0 \\
(0.0) \\
\end{array}$ & $\begin{array}{c}0 \\
(0.0)\end{array}$ & $\begin{array}{c}0 \\
(0.0) \\
\end{array}$ & $\begin{array}{c}0 \\
(0.0) \\
\end{array}$ & 1.7300 \\
\hline & Overall Mean & & & & & & & & 1.9566 \\
\hline
\end{tabular}

$1=$ Very unfavorable, $2=$ Unfavorable, $3=$ Somewhat unfavorable, $4=$ Neither favorable or unfavorable, $5=$ Somewhat favorable, $6=$ favorable, $7=$ Very Favorable; MAS = mean average score

\subsection{Regression Analysis}

Regression analysis run through SPSS in order to see the effect of Product-harm crisis on customer's based brand equity. Regression analysis technique is used for measuring the linear association between an independent and dependent variable. As this study consist of independent variable (Product-harm crisis) and dependent variable (Customer's Brand Equity).

\subsubsection{Product-Harm Crisis (PHC) and Customer's Based Brand Equity (BE)}

This study used regression analysis to examine the relation of Product-harm crisis and customer's based brand equity. The regression analysis results are presented in table below.
Table 4.8. Regression analyses of $\mathrm{PHC}$ and BE

\begin{tabular}{|c|c|c|c|c|c|c|}
\hline Variables & \multicolumn{7}{|c|}{ BE } \\
\hline & B & t-ratio & Sig. & F-ratio & P-value & $\mathbf{R}^{2}$ \\
\hline PHC & -.067 & -4.026 & 0.000 & 16.210 & 0.000 & 0.36 \\
\hline Constant & 2.701 & 39.888 & 0.000 & & & \\
\hline
\end{tabular}

$\mathrm{BE}=\beta_{0}+\beta_{1} \mathrm{PHC}$

$\mathrm{BE}=2.701+(-0.067)(\mathrm{PHC})$

\section{Interpretation}

In the above table 4.8 the value of $\mathrm{R}^{2}=0.36$ which shows that almost $36 \%$ change in $\mathrm{BE}$ is explained by PHC. As the t-ratio value is greater than $2(t>2)$ but negative and $\mathrm{P}$-value is significant with $\mathrm{P}<0.05$ and the F-statistics is 16.210 which is greater than 3 . From the above obtained results, sufficient base is available to argue that $\mathrm{PHC}$ has 
negative and significant effects on $\mathrm{BE}$.

\subsubsection{Moderating effects of Attitudes towards Brand} (ATB)

Table 4.9. Moderating effects of $\mathrm{ATB}$ on $\mathrm{PHC}$ and BE

\begin{tabular}{|c|c|c|c|c|c|c|}
\hline Variables & \multicolumn{5}{|c|}{ BE } & \\
\hline & B & t-ratio & Sig. & F-ratio & P-value & $\mathbf{R}^{2}$ \\
\hline PHC & -0.010 & -3.241 & 0.037 & 9.690 & 0.000 & 0.32 \\
\hline ATB & 0.056 & 4.559 & 0.026 & & & \\
\hline PHC*ATB & 0.012 & 3.928 & 0.000 & & & \\
\hline
\end{tabular}

\section{Interpretation}

The values in the above table state that $R^{2}$ value is changed with the introduction of moderating variable i.e. Attitude towards Brand (ATB) in the model. The results of the analyzed data suggested that if the customers are having strong ATB, it will results in lessen the negative effects of PHC on BE. F-Statistics value got reduce from previous value 16.210 to 9.690 with the introduction of moderator. Whereas P-value of F-Statistics is 0.000 $(\mathrm{P}<0.05)$ which means overall model is highly significant and good-fit.

\subsection{Average Perception of Customers Regarding PHC before and after Stone-walling Response by Company}

In order to test the significant difference between the average perception of customers regarding $\mathrm{PHC}$ before and after stone-walling response by company, normality test was run by using Shapiro-Wilk see appendices. And the result showed that data is not normally distributed. Thus non-parametric statistics test Wilcoxon signed-ranked test was used in order to test the $\mathrm{H}_{0}$ that there is no difference between average perception of customers regarding PHC before and after stone-walling response by the company. Wilcoxon test shows the following results:

Table 4.10. Average perception of customers regarding PHC before and after stone-walling using Wilcoxon signed-ranked test

\begin{tabular}{|c|c|c|c|c|c|}
\hline \multicolumn{2}{|c|}{ BEFORE } & \multicolumn{2}{|c|}{ AFTER } & \multirow[b]{2}{*}{ Z-ratios } & \multirow[b]{2}{*}{ Sig. } \\
\hline Mean & $\begin{array}{c}\text { Std. } \\
\text { Deviation }\end{array}$ & Mean & $\begin{array}{c}\text { Std. } \\
\text { Deviation }\end{array}$ & & \\
\hline 2.3583 & 0.08762 & 1.7632 & 0.06267 & -12.268 & 0.000 \\
\hline
\end{tabular}

\section{Interpretation}

The values in the above table 4.10 state that mean values of PHC changed from 2.3583 to 1.7632 . The stated values of mean in the above table suggested that brand equity of customer is reducing more as company responds in a stone-walling pattern. Thus the severity of PHC got intense when company responds in stone-walling manner. Which causes further reduction in the $\mathrm{BE}$ of the customers i.e. 0.5951

The result of Z-statistics is -12.268 with significance level P-value $=0.000(\mathrm{P}<0.05)$ which is less than -1.96 . It means that overall model is highly significant, and Stone-walling response has a significant effect on BE.

\section{Summary, Conclusion and Recommendations}

This chapter has illustrates the summary and conclusions based on findings obtained by analyzing product-harm crisis; customer's based brand equity and attitudes towards brand. Recommendations are also provided for further studies.

\subsection{Summary}

In order to investigate the effect of Product-harm crises on customer's based Brand Equity and the moderating role of Attitude towards Brand, this research was carried out. For the accomplishment this research, a primary data was gathered from 200 students as a sample. Purposive sampling technique was used in order to get the required number of respondents as a sample. Then questionnaires were disseminated among the undergraduate business students mentioned in table 3.1. The response of the respondents was measured by utilizing five points and seven points Likert scale. For reliability test of the collected data, Cronbach's alpha was used. At 0.05 levels of significance, regression analysis was used.

It is important to state that as the nature of this study and collected data is qualitative in nature so obtained values of coefficient of determination will be low, thus reliance was based primarily on t-ratio, $p$-value and f-value.

Regression analysis of PHC and BE (t-ratio $=-4.026$, $p$-value $=0.000, F$ value $=16.210$, and $R^{2}=0.36$ ) showed negative and highly significant relationship. Due to data noise, $R^{2}$ value is less as stated in book written by Gujarati. According to that book, when primary data is collected cross-sectionally, the calculated value $\mathrm{R}^{2}$ will be less than 0.90 . Thus this results rejected null hypothesis $\mathrm{H}_{0}$ and accepted alternate hypothesis i.e. PHC has significant effects on BE. This percentage figure depicts that: if the effect of PHC is not considered, it will result in negative $\mathrm{BE}$ of the customers. The relationship between PHC and $\mathrm{BE}$ has been addressed in various previous research studies, Dawar and Pillutla [3] has explained that mounting frequency of PHC have profound consequences for BE. Laufer and Coombs [70] also explained that negative effect of PHC causes negative effect on BE. Also Davies et al., [8] explained the negative effect of PHC on BE and company's product sales.

Moreover, after the induction of moderating variable Attitude towards Brand (ATB), the results regarding the interaction effect of $\mathrm{PHC} * \mathrm{ATB}$ and BE were counted as significant $(\mathrm{t}$-ratio $=3.928, \mathrm{p}$-value $=.000, \mathrm{~F}$ value $=15.431$, 
$\mathrm{R}^{2}=0.32$ ). Thus given results rejected null hypothesis $\mathrm{H}_{0}$ and accepted alternate hypothesis $\mathrm{H}_{2}$ i.e. ATB significantly moderates the relationship between PHC and BE. Deighton [111]; Hochanda [110]; Kopalleand Lehmann [112]; Olsonand Dover [113]; Smith et al., [109]; and Snyder and Swann [ 1 1 14$]$ in their studies found support for the interaction between ATB and BE when the evidence is either disconfirming or ambiguous.

In addition to that, inferences regarding effect of $\mathrm{PHC}$ on $\mathrm{BE}$ before and after stone-walling response showed that before stone-walling PHC has less severity and has brought less change in $\mathrm{BE}$ but after the stone-walling response of company, PHC has more stringent effects and thus brought more reduction in BE i.e. 0.5951 (Z-ratio $=-12.268$, p-value $=.000$, Mean values before $=2.3583$, Mean values ${ }_{\text {after }}=1.7632$ ). Thus null hypothesis $\mathrm{H}_{0}$ also rejected and alternate hypothesis $\mathrm{H}_{3}$ was accepted i.e. there is significant difference between average perception of customers regarding $\mathrm{PHC}$ before and after stone-walling.

If a company takes quick action in response to product-harm crises, it will protect their company's brand equity in customers mind. Thus favorable BE will leads to positive effects on consumer purchase intention. The finding of this research also supported the previous findings (Dawar and Pillutla [3], Laufer and Coombs [70] and Davies et al., [8]).

\subsection{Conclusion}

The research presented in this study provides many valuable managerial implications. Company's need to pay close attention towards negative effects of PHC as it's not only erode the base line of sale but also it cause a reduction in future sales of the company. Managers should avoid creating a negative public relations scenario during a product-harm crisis. Instead of fighting the recall, findings show it is preferable to comply with regulatory agencies and deal with the recall quickly and effectively. Company do need to focus their marketing efforts to regain their lost image the market by using different media like TV, internet and newspaper etc. Stone-walling involvement or eliciting no response to accusations of fault constitutes a negative public relations scenario. Company should make every possible effort to rectify the damage caused by their product to the target users. Complying with regulatory bodies, whether it is an involuntary, voluntary or super effort compliance strategy, will not necessarily win over customers and form positive associations but it can minimize customers grievances . However, compliance will avoid increasing attributions of blame towards the company. These findings are consistent with evidence that negative news bears far more weight than positive news (Dean [63]).

Results from this study are important for general management, consultants, investors and risk managers when planning future strategies.

\subsection{Future directions}

- This research has examined firm response i.e. stone-walling in product-harm crises and its interaction effects on customers based brand equity. Several other factors were kept constant which may affect brand equity and require further investigation. This includes the form of fault (delayed vs. internal), the timing of the response (immediate vs. delayed), product harm-crisis nature (acute versus chronic), the firm's response (voluntary versus legislated), and third-party interruptions as well as effect of firm response (e.g., product recall versus free replacement).

- Furthermore, given our interest in brand equity, our research examined only the impact on consumer's attitude towards brand. Other stakeholders may also be affected and may directly or indirectly affect brand equity. For example, perception of the victims, the media, investors, suppliers, the trade and regulatory authorities are likely to be pivotal in finding the overall impact of a PHC on the brand equity. This phenomenon deserves further research attention in marketing.

- Respondents were asked about only one type of product (Laptop) and were all young adults, which limit external validity.

- The current study also employed a rather homogeneous sample due to the average age and demographics of respondents. This was not representative of the greater population. Previous research suggests age may play a role in level of perceived risk. Therefore, this sample does not truly depict consumer reactions to a PHC because of feelings of invincibility amongst younger consumers (Laufer et al., [104]).

- The sample set also consists exclusively of business students, who have shown different attitudes than the general population (Benton, [115]; Ewert and Baker, [116]).

- As well, the sample constituted more males than females. Knowing that females are less forgiving in product-harm crises (Laufer and Gillespie, [73]), having more females in the sample might have strengthened results.

- The sample was comprised exclusively of commerce students, and it would be interesting to sample students in other academic disciplines to see if the results differed substantially. This homogenous sample may decrease the external validity of results, particularly when the study involved a critical business issue like product recalls. 
- Also, some products have emotional attachment (i.e. baby products, formula, medicine, etc.) which could play a role in the strength of reaction an individual has to a product denial. Including more than one product and/or scenario might also be considered to build external validity of the findings.
- Future research should also be extended to include other cultures. Hofstede's attitudinal research in uncertainty avoidance has shown there is a cultural element to consider when dealing with product-harm crises (Taylor, [105]; Laufer and Coombs, [70]).

\section{Appendix}

\section{World Top Four Selling Brands List:}

\begin{tabular}{|c|c|c|}
\hline Ranking & LAPTOP BRANDS & SELLING VOLUME (\%AGE) \\
\hline 1. & HP & $21.2 \%$ \\
\hline 2. & DELL & $16.5 \%$ \\
\hline 3. & TOSHIBA & $14 \%$ \\
\hline 4. & LENOVO & $7.3 \%$ \\
\hline
\end{tabular}

Source: http://money.cnn.com/2009/02/27/news/companies/lashinsky_hurd.fortune/index.ht

\section{HEC Recognized Universities List 2013 Updated}

\begin{tabular}{|c|c|c|}
\hline Sr. No. & Public Sector universities & Private Sector universities \\
\hline 1 & Khyber Medical university & Sarhad University of Science and Technology \\
\hline 2 & University of Peshawar & Gandhara University of Science and Technology \\
\hline 3 & KPK University of Engineering and Technology & City University of Science and Technology \\
\hline 4 & KPK University of Agriculture & CEOS university \\
\hline 5 & IMSciences & Abasyn University of Science and Technology \\
\hline 6 & Frontier Women university & \\
\hline 7 & Islamia College University & \\
\hline
\end{tabular}

Source: http:// www.hec.gov.pk/

\section{Academic Research Questionnaire}

\section{Effect of Product Harm-crises on Customer's Based Brand Equity: The Moderating Role of Attitude towards Brand}

\section{Study $1 \& 2$}

Read newspaper article attentively, while filling the following questionnaire. Here "X" means X laptop. Further directions on how to complete are provided within the questionnaire. 


\section{Product Harm-crisis:}

Please respond to the following questions by Ticking the appropriate response from 1 to 5 on the given scale.

\begin{tabular}{|c|c|c|c|c|c|}
\hline Items and Scales & $\begin{array}{l}\text { Strongly } \\
\text { disagree }\end{array}$ & Disagree & $\begin{array}{c}\text { Neither agrees nor } \\
\text { disagrees }\end{array}$ & Agree & $\begin{array}{c}\begin{array}{c}\text { Strongly } \\
\text { agree }\end{array} \\
\end{array}$ \\
\hline I feel the negative news reports about $X$ laptop serious. & & & & & \\
\hline $\begin{array}{l}\text { The news reports about } \mathrm{X} \text { laptop make me feel that its } \mathrm{X} \\
\text { laptops are involved with many risks. }\end{array}$ & & & & & \\
\hline $\begin{array}{l}\text { I feel that the negative news reports truly reveal the quality } \\
\text { problems of X laptop. }\end{array}$ & & & & & \\
\hline
\end{tabular}

\section{Brand Equity:}

\section{Brand Awareness:}

Please respond to the following questions by Ticking the appropriate response from 1 to 5 on the given scale.

\begin{tabular}{|c|c|c|c|c|c|}
\hline Items and Scales & $\begin{array}{l}\text { Strongly } \\
\text { disagree }\end{array}$ & Disagree & $\begin{array}{c}\text { Neither agree nor } \\
\text { disagree }\end{array}$ & Agree & $\begin{array}{c}\begin{array}{c}\text { Strongly } \\
\text { agree }\end{array} \\
\end{array}$ \\
\hline \multicolumn{6}{|l|}{ I can recognize $\mathrm{X}$ laptop among other competing brands. } \\
\hline \multicolumn{6}{|l|}{ I am aware of X laptop. } \\
\hline \multicolumn{6}{|l|}{ Some characteristics of X laptop come to my mind quickly. } \\
\hline \multicolumn{6}{|l|}{ I can quickly recall the symbol or logo of $\mathrm{X}$ laptop. } \\
\hline I have no difficulty in imagining $\mathrm{X}$ laptop in my mind. & & & & & \\
\hline
\end{tabular}

\section{Brand Loyalty:}

Please respond to the following questions by Ticking the appropriate response from 1 to 5 on the given scale.

\begin{tabular}{|c|c|c|c|c|c|}
\hline Items and Scales & $\begin{array}{l}\text { Strongly } \\
\text { disagree }\end{array}$ & Disagree & $\begin{array}{l}\text { Neither agrees or } \\
\text { disagrees }\end{array}$ & Agree & $\begin{array}{c}\text { Strongly } \\
\text { agree }\end{array}$ \\
\hline \multicolumn{6}{|l|}{ I intend to buy this brand in the near future. } \\
\hline \multicolumn{6}{|l|}{ I intend to buy other products of this brand. } \\
\hline \multicolumn{6}{|l|}{ I consider this brand as my first choice in this category. } \\
\hline \multicolumn{6}{|l|}{ The next time I need that product, I will buy the same brand. } \\
\hline \multicolumn{6}{|l|}{ I will continue to be loyal customer for this brand. } \\
\hline \multicolumn{6}{|l|}{$\begin{array}{l}\text { I am willing to pay a price premium over competing products to } \\
\text { be able to purchase this brand again. }\end{array}$} \\
\hline \multicolumn{6}{|l|}{$\begin{array}{l}\text { I would only consider purchasing this brand again, if it would be } \\
\text { substantially cheaper. }\end{array}$} \\
\hline \multicolumn{6}{|l|}{ I say positive things about this brand to other people. } \\
\hline \multicolumn{6}{|l|}{ I recommend this brand to someone who seeks my advice. } \\
\hline \multicolumn{6}{|l|}{ I intend to recommend this brand to other people. } \\
\hline \multicolumn{6}{|l|}{ I consider this brand my first choice in the next few years. } \\
\hline \multicolumn{6}{|l|}{ I get good value for my money. } \\
\hline \multicolumn{6}{|l|}{ I consider myself to be loyal to $\mathrm{X}$ laptop. } \\
\hline X laptop would be my first choice. & & & & & \\
\hline $\begin{array}{c}\text { I will not buy other brands if } \mathrm{X} \text { laptop is available at the same } \\
\text { store. }\end{array}$ & & & & & \\
\hline
\end{tabular}




\section{Brand Image:}

Please respond to the following questions by Ticking the appropriate response from 1 to 5 on the given scale.

\begin{tabular}{|c|c|c|c|c|c|}
\hline Items and Scales & $\begin{array}{l}\text { Strongly } \\
\text { disagree }\end{array}$ & Disagree & $\begin{array}{l}\text { Neither agrees } \\
\text { or disagrees }\end{array}$ & Agree & $\begin{array}{c}\text { Strongly } \\
\text { agree }\end{array}$ \\
\hline \multicolumn{6}{|l|}{ I have a clear understanding on this brand. } \\
\hline \multicolumn{6}{|l|}{ Symbol of the brand can build recognition to me. } \\
\hline \multicolumn{6}{|l|}{$\mathrm{X}$ laptop comes to my mind at first when mentions laptop companies. } \\
\hline \multicolumn{6}{|l|}{ I like X laptop very much. } \\
\hline \multicolumn{6}{|l|}{ I am satisfied with X laptop quality. } \\
\hline \multicolumn{6}{|l|}{ The product quality of the brand is good. } \\
\hline \multicolumn{6}{|l|}{ I recognize this brand when I have a need of laptop. } \\
\hline \multicolumn{6}{|l|}{ The brand image is outstanding and gives me a good impression. } \\
\hline \multicolumn{6}{|l|}{ The values of this brand give me confidence to its products. } \\
\hline \multicolumn{6}{|l|}{ The product attributes can fulfill my functional and emotional needs. } \\
\hline \multicolumn{6}{|l|}{ I can specifically point out $\mathrm{X}$ laptop advantages. } \\
\hline \multicolumn{6}{|l|}{ Use of this brand can express my personality. } \\
\hline \multicolumn{6}{|l|}{ This brand provides a variety of products. } \\
\hline \multicolumn{6}{|l|}{ This is the leading brand in the market. } \\
\hline \multicolumn{6}{|l|}{ I will purchase when X laptop will launch new product. } \\
\hline \multicolumn{6}{|l|}{$\mathrm{X}$ laptop is different from other laptops. } \\
\hline \multicolumn{6}{|l|}{$\mathrm{X}$ laptop is my first choice. } \\
\hline \multicolumn{6}{|l|}{ I am satisfy with this brand but will try other brand next time. } \\
\hline \multicolumn{6}{|l|}{ I am pleased to repurchase this brand. } \\
\hline \multicolumn{6}{|l|}{ I will buy X laptop even no advertisement. } \\
\hline I will insist on buying $\mathrm{X}$ laptop even other new laptops are launched. & & & & & \\
\hline
\end{tabular}

\section{Perceived Quality:}

Please respond to the following questions by Ticking the appropriate response from 1 to 5 on the given scale.

\begin{tabular}{|c|c|c|c|c|c|}
\hline Items and Scales & $\begin{array}{l}\text { Strongly } \\
\text { disagree }\end{array}$ & Disagree & $\begin{array}{c}\text { Neither agrees or } \\
\text { disagrees }\end{array}$ & Agree & $\begin{array}{c}\begin{array}{c}\text { Strongly } \\
\text { agree }\end{array} \\
\end{array}$ \\
\hline \multicolumn{6}{|l|}{$\mathrm{X}$ laptop is of high quality. } \\
\hline \multicolumn{6}{|l|}{ The likely quality of $\mathrm{X}$ laptop is extremely high. } \\
\hline \multicolumn{6}{|c|}{ The likelihood that X laptop would be functional is very high. } \\
\hline \multicolumn{6}{|l|}{$\mathrm{X}$ laptop appears to be reliable. } \\
\hline \multicolumn{6}{|l|}{$\mathrm{X}$ laptop must be of very good quality. } \\
\hline \multicolumn{6}{|l|}{$\mathrm{X}$ laptop appears to be of very poor quality. } \\
\hline $\mathrm{X}$ laptop appears not to be of very poor quality & & & & & \\
\hline
\end{tabular}

\section{Attitude toward Brand:}

Please respond to the following questions by Ticking the appropriate response from 1 to 7 on the given scale.

a). My general opinion of X laptop is:

1. Very unfavorable

2. Unfavorable

3. Somewhat unfavorable

4. Neither favorable or unfavorable

5. Somewhat favorable

6. Favorable 
7. Very favorable

b). I feel that overall, $\mathrm{X}$ laptop is:
1. Very bad
2. Bad
3. Somewhat bad
4. Neither good or bad
5. Somewhat good
6. Good
7. Very good

c). My overall view of $\mathrm{X}$ laptop is:

1. Very Negative

2. Negative

3. Somewhat Negative

4. Neither positive or Negative

5. Somewhat positive

6. Positive

7. Very positive

Todar's Daper | Anchive |

Grovp Oairman: Mir Javed Ratmat

\section{THENEWS}

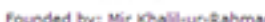

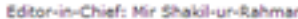

fire and the user's house was bumed down. Two people were seriously injured and same case were also found in some other areas of the world. Also many cases of eye disease were recorded from the different commtries of the world because of emission of dangerous rays fom their laptops LCDs. (The NEWS Ad Dated: 05-05-2014 Time: 14:30 GST

Todar's Paper | Anchive |

\section{THENEWS}

Grovp Oairman: Mir Javed Ratman

Response by CEO of XInc::

In reference to the ad dated: $05-05-2014$ Time: $14: 30$ GST response to thereport against $X$ Inc. After the crisis happened, CEO of $\mathrm{X}$ Inc. quickly argued that all of its laptops were appropriately made and denied responsibility for the incident. 


\section{REFERENCES}

[1] Kotler P. Marketing management/Philip Kotler, Kevin Lane Keller. Pearson Education Limited. 2012; 817:1.

[2] Wood, L. (2000) 'Brands and brand equity: Definition and management', Management Decision, Vol. 38, No. 9, pp. $662-669$

[3] Dawar, N. and Pillutla, M. M., 2000. Impact of product-harm crises on brand equity: the moderating role of consumer expectations. Journal of Marketing Research, 37: 215-226.

[4] Dawar, N. and Lei, J. 2008. Brand crises: the role of brand familiarity and crisis relevance in determining the impact on brand evaluation. Journal of Business Research, Vol. 62(4): pp. 509-16.

[5] Aaker. D.A. 1991. Managing Brand Equity: Capitalizing on the Value of a Brand Name, The Free Press New York

[6] Matos, C. A. and Rossi, C. A. V. 2007. Consumer reaction to product recalls: factors influencing product judgment and behavioural intentions. International Journal of Consumer Studies, Vol. 31(1): pp. 109-16.

[7] Maher, J. 2005. UT javelin champ says bad taco killed dream. Austin-American statesman: pp.C1.

[8] Davies, H., Walters, M., 1998. Do All crises have to become disasters? Risk and risk mitigation. Disaster Prevention and Management 17 (5): 396-400.

[9] Siomkos, G. J. and Kurzbard, G. 1994. The hidden crisis in product-harm crisis management. European Journal of Marketing, 28(2):pp. 30-41.

[10] Pruitt, S. W. and Peterson, D. R. 1986. Security price reactions around product recall announcement. Journal of Financial Research, Vol. 9(2): pp. 113-22.

[11] McDaniel, S. R., L. Kinney and L. Chalip. 2004. A Cross-Cultural Investigation of the Ethical Dimensions of Alcohol and Tobacco Sports Sponsorships. Teaching Business Ethics, 5(3): 307-330.

[12] [12] Hill, R. P. 2002. Stalking the poverty consumer: A retrospective examination of modern ethical dilemma. Journal of Business Ethics, 37: 209-219.

[13] Wallendorf, M. 2001. Literally Literacy. Journal of Consumer Research 27: 505-511.

[14] Nwachukwu, S. L. S., S. J. Vitell, Jr., F. W. Gilbert and J. H. Barnes. 1997. Ethics and Social Responsibility in Marketing: An Examination of the Ethical Evaluation of Advertising Strategies. Journal of Business Ethics 39: 107-118.

[15] Berman, B. 1999. Planning for the inevitable product recall. Business Horizons, 42(2): 69- 78 .

[16] Fishbein, Martin, and IcekAjzen. 1975. Belief, Attitude, Intention and Behavior: An Introduction to Theory and Research. Journal of Advertising, 14 (1): 10-17.

[17] Kanouse, David and Reid L. Hanson, Jr. 1972. Negativity in Evaluations, in Attribution. Perceiving the Causes of Behavior, E.E. Jones et al. Eds., Morristown, NJ: General Learning Press.
[18] Shimp and Terence. 1981. Attitude toward the Brand as a Mediator of Consumer Brand Choice. Journal of Advertising, 34(6): 9-15.

[19] Lutz and Richard J. 1975. Changing Brand Attitudes through Modification of Cognitive Structure. Journal of Consumer Research, 1(4): 49-59.

[20] Olson, Jerry C. and Mitchell A. A. 1975. The Process of Attitude Acquisition: The Value of a Development Approach to Consumer Research, in Advances in Consumer Research, (6), William Wilkie, (ed). Ann Arbor, MI: Association for Consumer Research, 34 (3): 269-275.

[21] Eagly, Alice H. and Shelly Chaiken. 1993. The Psychology of Attitudes. New York Harcourt Brace College Publishers.

[22] Bagozzi and Richard P. 1981. Attitudes, Intentions, and Behavior: A Test of Some Key Hypotheses. Journal of Personality and Social Psychology, 41: 607-27.

[23] Ostrom and Thomas M. 1969. The Relationship between the Affective, Behavioral, and Cognitive Components of Attitude. Journal of Experimental social psychology, 5: 12-30.

[24] Mitchell A. A., and Olson. 1981. Are Product Attribute Beliefs the Only Mediator of Advertising Effects on Brand Attitude. Journal of Marketing Research, 18(3): 318-32.

[25] Giner-Sorolla and Roger. 1999. Affect in Attitude: Immediate and Deliberative Perspectives, in Dual-Process Theories in Social Psychology, Shelley Chaiken and Yaacov Trope, (Eds). The Guilford Press: New York, 441-61.

[26] Ching-Fu Chen and Yu-Ying Chang. 2008. Airline Brand equity, Brand preference, and Purchase intentions - the moderating effects of switching costs. Journal of Air Transport Management, 14: 40-42.

[27] Cobb-Walgren, C. J., Ruble, C. A. and Donthu, N. 1993. Brand equity, Brand preference and Purchase intention. Journal of Advertising 24 (3): 25-40.

[28] Keller, K. L. 1993. Conceptualizing, Measuring and Managing Customer-Based Brand Equity, Journal of Marketing Research, vol.29 (2): pp.35-50.

[29] Keller, K. L. 2003. Strategic Brand Management: Building, Measuring and Managing Brand Equity, Pearson, Upper Saddle River, NJ.

[30] Holden, S. 1993. Understanding brand awareness: let me give you a clue!. Advances in Consumer Research, Vol. 20: pp. 383-8.

[31] Laurent, G., Kapferer, J. and Roussel, F. 1995. The underlying structure of brand awareness scores. Marketing Science, Vol. 14: pp. 170-9.

[32] Mariotti, J. 1999. Smart Things to Know about Brands and Branding. Capstone Publishing, London.

[33] Elliott, D., Harris, K. and Baron, S., 2005. Crisis management and services marketing. Journal of Services Marketing 19 (5): 336-345.

[34] Rossiter, J. R. and Percy, L. 1997. Advertising Communications and Promotion Management, McGraw-Hill, Boston, MA. 
[35] Ross, J. and Harradine, R. 2004. I am not wearing that! Branding and young children.

[36] Jacoby, J. and D. Kyner. 1973. Brand Loyalty versus Repeat Purchase Behavior. Journal of Marketing Research, Vol. 10 pp. 1-9.

[37] Reichheld, F. F. 1996. The Loyalty Effect. Harvard Business School Press, Boston, MA.

[38] Mustafa T., 1999. Increasing brand loyalty in the hospitality industry. International Journal of Contemporary Hospitality Management, 11(5): pp. 223-229.

[39] Berry, L., Lefkowith, E. and Claek, T. 1988. In services, what's in a name? Harvard Business Review, Vol. 66: pp. 28-32.

[40] Park, C. W., B.J. Jaworski, and D.J. Maclnnis. 1986. Strategic Brand Concept-Image Management. Journal of Marketing, Vol.50: pp. 135-145

[41] Schiffman, L. and Kanuk, L. 1991. Consumer Behavior, Prentice-Hall, Englewood Cliffs, NJ.

[42] Elliott, T. L. III. 1996. Brand management: what's in store?. Telephony, Vol. 231(6): pp. 305.

[43] Aikaterini V., George S., Kalliopi C. and Angelos P., 2009. Product-harm crisis management: Time heals all wounds? Journal of Retailing and Consumer Services, 16: 174-180.

[44] Shrivastava, P. and Siomkos, G. J. 1989. Disaster containment strategies. Journal of Business Strategy, Vol. 10(5): pp. 26-30.

[45] Weinberger, M. G. and Romeo, J. B., 1989. The impact of negative product news. Business Horizons, 32: 44-50.

[46] Jolly, D. and Mowen, J., 1984. Product recall communications: the effects of source, media, and social responsibility information. Advances in Consumer Research, 12: $471-475$.

[47] Weinberger, M. G. 1986. Products as targets of negative information: some recent findings. European Journal of Marketing, 20: 110-127.

[48] Mowen, J. C. 1980. Further information on consumer perceptions of product recalls. Advances in Consumer Research, Vol. 7: pp. 519-23.

[49] Siomkos, G. and Shrivastava, P., 1993. Responding to product liability crises. Long Range Planning, 26 (5): 72-79.

[50] Coomsbs, T. W. 1995. Choosing the right words: the development of guidelines for the selection of the "appropriate", crisis response strategies. Management Communication Quarterly, Vol. 8: 447-476.

[51] Mitroff, I.I., and Pearson, C.M. 1993. Crisis Management: A Diagnostic Guide for Improving Your Organization's Crisis Preparedness. Jossey Bass, San Francisco.

[52] Griffin, M., Babin, B. J. and Attaway, J. S. 1991. An empirical investigation of the impact of negative publicity on consumer attitudes and intentions. Advances in Consumer Research, Vol. 18: pp. 334-41.

[53] Jorgensen, B. K. 1994. Consumer reaction to company-related disasters: the effect of multiple versus single explanations. Advances in Consumer Research, 21:
$348-352$.

[54] Jorgensen, B. K. 1996. Components of consumer reaction to company related mishaps: a structural equation model approach. Advances in Consumer Research, 23: 346-351.

[55] Cleeren, K., Dekimpe, M. G. and Helsen, K. 2006. Weathering Product-harm Crises. Department of Marketing and Organisation Studies (MO), Katholieke University Leuven, Leuven, pp. 262-70.

[56] Klein, J. and Dawar, N. 2004. Corporate social responsibility and consumers' attributions and brand evaluations in a product-harm crisis. International Journal of Research in Marketing, Vol. 21: pp. 203-17.

[57] Griffin, M., Babin, B. J. and Darden, W. R. 1992. Consumer assessments of responsibility for product-related injuries: the impact of regulations, warnings, and promotional policies", in Sherry, J. F. Jr and Sternthal, B. (Eds). Advances in Consumer Research, Vol. 19: pp. 870-8.

[58] Baolong M., Lin Zhang, Fei Li and Gao Wang. 2010. The effects of product-harm crisis on brand performance. International Journal of Market Research, Vol. 52(4).

[59] Mowen, J. C. and Ellis, H. W. 1981. The product defect: management and consumer implications, in Enis, B. and Roering, K. (Eds), Review of Marketing, American Marketing Association, Chicago, IL: pp. 158-72.

[60] Siomkos, G. and Malliaris, P. 1992. Consumer response to company communications during a product harm crisis. Journal of Applied Business Research 8 (3): 1-9.

[61] Roehm, M. L. and Tybout, A. M. 2006. When will a brand scandal spillover and how should competitors respond?, Journal of Marketing Research, Vol. 53(3): pp. 366-73.

[62] Dean, D.H. 2004. Consumer reaction to negative publicity: effects of corporate reputation, response, and responsibility for a crisis event. Journal of Business Communication, Vol. 41: pp. 192-211.

[63] Siomkos, G.J. 1999. On achieving exoneration after a product safety industrial crisis. Journal of Business and Industrial Marketing, Vol. 14: pp. 17-29.

[64] Wiener, J. and Mowen, J. C. 1985. Product recalls: avoiding beheading the messenger of bad news. Mobius, Vol. 4: pp. $18-21$.

[65] Folkes, V. S. 1984. Consumer reactions to product failure: an attributional approach. Journal of Consumer Research, Vol. 10: pp. 398-409.

[66] Folkes, V.S. 1988. Recent attribution research in consumer behavior: a review and new directions. Journal of Consumer Research, Vol. 14: pp. 548-65.

[67] Richins, M. 1983. Negative word of mouth by dissatisfied consumers: a pilot study. Journal of Marketing, Vol. 47: pp. 68-78.

[68] Laczniak, R. N., DeCarlo, T. E. and Ramaswami, S. N. 2001. Consumers' response to negative word-of-mouth communication: an attribution theory perspective. Journal of Consumer Psychology, Vol. 11(1): pp. 57-73.

[69] Laufer, D. and Coombs, T. W. 2006. How should a company respond to a product harm crisis? The role of corporate 
reputation and consumer based cues. Business Horizons, Vol. 49: pp. 379-85.

[70] Kelly, K. T. and Campbell, J. L. 1997. Attribution of responsibility for alcohol related offences. Psychological Reports, 80: 1159-1165.

[71] Tedeschi, J. T. and Nesler, M. S. 1993. Grievances: development and reactions. In: Felson, R.B. (Ed.), Aggression and Violence: Social Interactionist Perspectives. American Psychological Association, Washington, DC: pp. 13-46.

[72] Laufer, D., Gillespie, K., B, M., and Gonzalez, S. 2005. The role of severity in consumer attributions of blame: Defensive attributions in product harm crises in Mexico. Journal of International Consumer Marketing, 33-50.

[73] Folkes, V. S. and Kotsos, B. 1986. Buyers' and sellers' explanations for product failure: who done it?. Journal of Marketing, Vol. 50: pp. 74-80.

[74] Slovic, P. 1987. Perception of risk. Journal of Management Science, Vol. 236: pp. 280-5.

[75] Paswan, A. K., Spears, N. and Ganesh, G. 2007. The effects of obtaining one's preferred service brand on consumer satisfaction and brand loyalty. Journal of Services Marketing, Vol. 21(2): pp. 75-87.

[76] Tsang, A. S. L. 2000. Military doctrine in crisis management: three beverage contamination cases. Business Horizons, pp. 65-73.

[77] Eagle, L., Hawkins, J., Kitchen, P. J. and Rose, L. C. 2005. Brand sickness and health following major product withdrawals. Journal of Product and Brand Management, Vol. 14(5): pp. 310-21.

[78] Frewer, L.J. and Shepherd, R. 1999. Consumer perceptions of modern food biotechnology", in Roller, S. and Harlander, S. (Eds), Genetic Modification in the Food Industry. Blackie Academic and Professional, London, pp. 27-46.

[79] Kasperson, R. E., Renn, O., Slovic, P., Brown, H. S., Emel, J., Goble, R., Kasperson, J. X. and Raticks, S. 1988. The social amplification of risk: a conceptual framework. Risk Analysis, Vol. 8: pp. 177-87.

[80] Huang, Y. 2008. Trust and relational commitment in corporate crises: the effects of crisis communicative strategy and form of crisis response. Journal of Public Relations Research, Vol. 20(3): pp. 297-327.

[81] Jones, G., Jones, B. and Little, P. 2000. Reputation as reservoir: the value of corporate goodwill as a buffer against loss in times of economic crisis. Corporate Reputation Review, 3 (1): 21-29.

[82] Mak, A. K. 2005. Identity-centered model of reputation management: a case study of Iowa tourism office and its industry partners. In: Proceedings of the Eighth International Public Relations Research Conference on The Impact of PR in Creating a More Ethical World: Why Can't we Get Along?, Best Western South Miami, FL, 10(13): pp. 270 291.

[83] Fombrun, C. J. and VanRiel, C. B. M. 2003. Fame and Fortune: How Successful Companies Build Winning Reputations. Prentice-Hall Financial Times, New York.
[84] Laufer D., Gillespie K. and David H. Silvera: 2009. The Role of Country of Manufacture in Consumers' Attributions of Blame in an Ambiguous Product-Harm Crisis. Journal of International Consumer Marketing, 21: 189-201.

[85] Yubo C., Shankar G. and Yong L., 2009. Does a Firm's Product-Recall Strategy Affect Its Financial Value? An Examination of Strategic Alternatives during Product-Harm Crises. Journal of Marketing Vol. 73: 214-226.

[86] Nancy Spears. And Surendra N. Singh. 2004. Measuring Attitude toward the Brand and Purchase Intentions. Journal of Current Issues and Research in Advertising, 26(2): 53-66.

[87] Heath R.G. 2007. Emotional Persuasion In Advertising: A Hierarchy-of-Possessing Model. Journal of Advertising Research, 45(2): 269-281.

[88] Gardner, Meryl Paula. 1985. Does Attitude Toward the Ad Effect Brand Attitude Under a Brand Evaluation Set?. Journal of Marketing Research, 22: 192-198.

[89] Brown and Douglas M. Stayman. 1992. Antecedents and Consequences of Attitude toward the Ad: A Meta Analysis. Journal of Consumer Research, 19: 35-51.

[90] Biehal G., Stephens D., and Curlo E. 1992. Attitude toward the Ad and Brand Choice. Journal of Advertising, 21(3): 19-36.

[91] MacKenzie, Scott B. and Richard J., Lutz, and George E., Belch. 1986. The Role of Attitude toward the Ad as a Mediator of Advertising Effectiveness: A Test of Competing Explanations. Journal of Marketing Research, 23(2): 130-43.

[92] Muehling, Darrel D., and Russell N., Laczniak. 1988. Advertising's Immediate and Delayed Influence on Brand Attitudes: Considerations across Message Involvement Levels. Journal of Advertising, 17(4): 23-34.

[93] Shams R., 2005. Review the relationship among selected marketing mix components and brand equity of mobiles in young age group of Tehran city. Thesis system of Tehran University.

[94] Yumi L. and Pamela A. Weaver. 2012. Customer-based Brand Equity for a Destination: the Effect of Destination Image on Preference for Products Associated with a Destination Brand. International Journal of Tourism Research, Int. J. Tourism.

[95] Lagazian S., 2007. Consumer and the state of evaluating the brand value: A study in Hotel management industry.

[96] Zarbi S., 2006. Evaluation of selected marketing mix component on brand equity. Marketing management magazine of the Islamic Azad University, science and research branch, third quarterly periodical, 21-58.

[97] Chattopadhyay.T, Dutta. R. N, Sivani. S. 2010. Media mix elements affecting brand equity: A study of the Indian passenger car market. IIMB Management Review, doi:10.1016/j.iimb.2010.09.001.

[98] Hua.W. 2005. The effects of marketing mix on brand equity. Thesis of Hong Kong University.

[99] Villarejo-Ramos. A. F. and Sanchez-Franco.M. J. 2005. The impact of marketing communication on brand equity. Journal of consumer studies, Vol. 30(1): pp. 108-16. 
[100] Dawar, N. 2010. Examination of Nuanced effects of product-harm crises on brand equity. ISSN no. 0317-9869: ISBN no. 0-7714-2267-9.

[101] Niazi A. M., Ghani U. and S. Aziz. 2012. The Emotionally charged advertisement and their influence on Consumers' Attitudes. International Journal of Business and Social Science, Vol. 3(1)

[102] Michelle L. Roehm and Michael K. Brandy. 2007. Consumer Responses to Performance Failures by High-Equity Brands. Journal of consumer research.

[103] Laufer, D., Silvera, D.H. and Meyer, T. 2005. Exploring differences between older and younger consumers in attributions of blame of product harm crises. Academy of Marketing Science Review, Vol. 2005(7): pp. 1-21.

[104] Taylor SE, Klein LC, Lewis BP, Gruenewald TL, Gurung RA, Updegraff JA. Biobehavioral responses to stress in females: tend-and-befriend, not fight-or-flight. Psychological review. 2000 Jul; 107(3):411.

[105] BoongheeYoo and Naveen Donthu. 2001. Developing and validating a multidimensional consumer-based brand equity scale. Journal of Business Research, Vol. 52: pp: 1-14.

[106] Zeithaml, V. A. 1988. Consumer Perceptions of Price, Quality, and Value: A Means End Model and Synthesis of Evidence. Journal of Marketing, 52 (3): 2-22.

[107] Hair, J., Babin, B., Money, A., \&samouel, P. (2003). Essentials of Business research Methods. Wiley

[108] Smith, C. N., Thomas, R. J., and Quelch, J. A. 1996. A strategic approach to managing brand equity. Journal of marketing, Vol. 55(1): 22-89.

[109] Hoch, Stephen J. and Young-Won Ha (1984), "Consumer Learn- ing: Advertising and the Ambiguity of Product
Experience," Journal of Consumer Research, 13 (September), 221-33.

[110] Deighton, John (1984), "The Interaction of Advertising and Evi- dence," Journal of Consumer Research, 11 (December), 763- 70 .

[111] KopallePK, Lehmann DR. The effects of advertised and observed quality on expectations about new product quality. Journal of Marketing Research. 1995 Aug 1:280-90.

[112] Olson JC, Dover PA. Disconfirmation of consumer expectations through product trial. Journal of Applied psychology. 1979 Apr; 64(2):179.

[113] Snyder M, Swann WB. Behavioral confirmation in social interaction: From social perception to social reality. Journal of Experimental Social Psychology. 1978 Mar 31; 14(2):148-62

[114] Benton AL, K. deS. Hamsher, Sivan AB. Multilingual Aphasia Examination: Token Test. AJA associates; 1994

[115] Ewert A, Baker D. Standing for where you sit: An exploratory analysis of the relationship between academic major and environment beliefs. Environment and Behavior. $2001 \mathrm{Sep} ; 33(5): 687-707$

[116] Eilert, M., Kalaignanam, K., Jayachandran, S., \& Swartz A T. (2017). Does It Pay to Recall Your Product Early? An Empirical Investigation in the Automobile Industry. American Marketing Association., 1-53. https://doi.org/https://doi.org/10.1509/jm.15.0074

[117] Hsu, L., \& Lawrence, B. (2016). The role of social media and brand equity during a product recall crisis: A shareholder value perspective. International Journal of Research in Marketing, 33(1), 59-77. https://doi.org/10.1016/j.ijresmar.2015.04.004 